\title{
The Place of Labor Rights in the European Union's Environmental Policies
}

\author{
Pascal McDougall* \\ S.J.D. Program, Harvard Law School, Cambridge, Massachusetts, United States
}

(Received 25 July 2020; revised 26 September 2020; accepted 11 October 2020)

\begin{abstract}
This Article analyzes the potential impact of the European Commission's proposed "European Green Deal" on labor rights, in particular the rights of workers in lower-income EU Member States. It focuses on environmental measures, already part of the EU's existing environmental policies and further contemplated in the Green Deal, which prohibit or tax certain polluting production processes. Such measures, insofar as they apply uniformly to traded-good industries, are likely to make firms in lower-income EU Member States less competitive and harm their workers' rights to work and to fair wages. Thus, even though these environmental measures are worth pursuing for the benefits they procure, the distribution of their costs is likely to run afoul of egalitarian norms. This Article puts forward an institutionalist approach to trade theory which recognizes that competitiveness is legally constructed. It argues on the basis of that theory that lower-income countries should be allowed to adopt ambitious industrial policies and subsidize their firms to insulate workers from the disruptions caused by added environmental regulatory costs. More broadly, this Article presents an agenda to pursue radical environmental transformation while remedying, or at least not worsening, inequalities between workers and citizens in the EU.
\end{abstract}

Keywords: European Green Deal; labor law; just transition; state aid; environmental justice

\section{A. Introduction}

In December 2019, the European Commission announced an ambitious environmental agenda for the European Union called the "European Green Deal."1 This agenda lays out the goal of having zero net emissions of greenhouse gas ${ }^{2}$ by 2050 and proposes a series of measures "to green" the economy on the production and consumption sides. The Commission frames the Green Deal not only as an environmental plan but also as a "new growth strategy that aims to transform the EU into a fair and prosperous society, with a modern, resource-efficient and competitive economy." During the summer of 2020, the Commission and the European Council have stated that they see

\footnotetext{
${ }^{*}$ Adjunct Lecturer, Sciences Po, Paris; S.J.D. Candidate, Harvard Law School.

${ }^{1}$ The European Green Deal: Communication From the Commission to the European Parliament, the European Council, the Council, the European Economic and Social Committee and the Committee of the Regions, at 11, COM (2019) 640 final (Dec. 11, 2019) [hereinafter European Green Deal].

${ }^{2}$ Zero "net" emissions means that any greenhouse gas emission that is not eliminated must be neutralized by natural or constructed means of "carbon sequestration," which refers to the absorption of carbon emissions so that they do not reach the atmosphere. Forests are a classic example of natural carbon sequestration. See What Is Carbon Neutrality and How Can It Be Achieved by 2050?, EUR. PARLIAMENT (Mar. 10, 2019), https://www.europarl.europa.eu/news/en/headlines/society/ 20190926STO62270/what-is-carbon-neutrality-and-how-can-it-be-achieved-by-2050.

${ }^{3}$ European Green Deal, supra note 1, at 2.
} 
"[t]he European Green Deal as the EU's recovery strategy" from the COVID-19-induced economic contraction. ${ }^{4}$ Importantly, the Green Deal also acknowledges that "transition can only succeed if it is conducted in a fair and inclusive way" and that "not all Member States, regions and cities start the transition from the same point or have the same capacity to respond." The Green Deal contains several measures, described below, to redistribute the burden of the transition instead of letting losses lie where they fall under the proposed new environmental measures.

Environmental policy at the international level, for its part, has long featured much discussion of the differentiated ability of states and regions to shoulder the costs of environmental protection. ${ }^{6}$ This is perhaps not surprising, given the abysmal international disparities in income and power. Moreover, discussions of the distributive stakes of international environmental law have often focused on colonial and quasi-colonial legacies. ${ }^{7}$ By contrast, the traditionally dominant approach of international environmental law had been that of seeking to form a "normative program for the world community." ${ }^{\circ}$ Those who hold with this traditional approach see human beings as sharing a common responsibility and interest in preserving the environment and deplore that "environmental law has been used [by lower-income countries] as a subterfuge to bring distributive issues in the international debate." In my view, the foregrounding by policy-makers and scholars of unequal wealth and environmental capacity, as well as post-colonial justice issues, has been a useful corrective to international environmental law's traditional approach. Even more helpful extensions of the distributive approach to international environmental law have emphasized intra-state distributive conflicts and the interests of disfavored citizens and communities in obtaining better living conditions under an environmental transition. ${ }^{10}$

In EU environmental law, at least up until the Green Deal, there has been less emphasis on the distributive impact of environmental measures-as between Member States or as between individuals and groups more generally. ${ }^{11}$ The absence of any past intra-European colonial relationship and the higher degree of economic uniformity between the countries might explain this lesser emphasis in EU law than at the international level. One way in which the distributive impact of EU environmental policy has been discussed is through a conflation of the environment with labor and other "social" issues in opposition to "the market" or "free trade." ${ }^{2}$ In this approach, the

\footnotetext{
${ }^{4}$ Europe's Moment: Repair and Prepare for the Next Generation, Eur. Comm'N (May 27, 2020, 1:37 PM), https://ec.europa. eu/commission/presscorner/detail/en/ip_20_940. See also Special European Council, 17-21 July 2020, THE EuR. CounCIL, https://www.consilium.europa.eu/en/meetings/european-council/2020/07/17-21/ (last visited July 22, 2020).

${ }^{5}$ European Green Deal, supra note 1, at 16.

${ }^{6}$ See infra Section D(I).

${ }^{7} I d$.

${ }^{8}$ Pierre-Marie Dupuy, Soft Law and the International Law of the Environment, 12 MiCH. J. INT'L L. 420, 422 (1991).

${ }^{9}$ Elli Louka, International Environmental Law: Fairness, EFFectiveness, and World Order 70 (2007).

${ }^{10}$ See, e.g., Kishan Khoday \& Usha Natarajan, Fairness and International Environmental Law from Below: Social Movements and Legal Transformation in India, 25 LEIDEN J. INT'L L. 415, 437-39 (2012).

${ }^{11}$ There are nevertheless several policy mechanisms within the EU legal order to change the distributive impact of EU environmental measures as between Member States. See infra notes 183-85 and accompanying text.

${ }^{12}$ See Joseph H. Weiler, The Transformation of Europe, 100 YALE L.J. 2403, 2487-88 (1991) (describing "environmental protection" and the "social package of employees" as parts of a sphere opposed to-but rendered necessary by the operation of- "the market"); Miguel Poiares Maduro, Reforming the Market or the State? Article 30 and the European Constitution: Economic Freedom and Political Rights, 3 EuR. L.J. 55, 66-67, 71, 74 (1997) (describing a conflict between "economic freedom" and "free market competition" on the one hand and "market-correcting intervention" and "social values" on the other hand, identifying environmental protection firmly with the latter); Bob Hepple, Social Values and European Law, 48 CURRENT LEGAL Probs. 39, 50 (1995) (exploring possibilities of conflict between "neoliberal" market freedoms and "social" issues including labor rights and the "conservation of the environment"); Floris de Witte, EU Law, Politics, and the Social Question, 14 GERMAN L.J. 581, 582 (2013) (putting "labor regulations" and "environmental policies" at the core of a social sphere against which "the market" and "capitalism" are opposed); Norbert Reich, A European Constitution for Citizens: Reflections on the Rethinking of Union and Community Law, 3 EuR L.J. 131, 133 (1997) (describing "ecological rights" and "social rights" as two of the categories of "additional rights" superposed on the "nucleus" of "economic rights" granted by the EU legal order); Tamara Hervey, Social Solidarity: A Buttress Against Internal Market Law?, in Social LAW AND Policy IN AN Evolving
} 
market left alone might lead to environmental destruction and the erosion of labor rights-such that social and environmental regulation at the European level might be necessary to counter the negative distributive impact of markets. This trope resonates with a widespread dichotomization of the social and market spheres in EU legal theory more generally. ${ }^{13}$

In this Article, I propose an approach that fully incorporates the distribution of income and economic power as a paramount consideration in EU environmental policy-but, at the same time, avoids what I see as the trap of describing the environment as a "social" issue incompatible with the logic of the internal market. In so doing, I hope to provide general reflections and guidelines that could inspire policy-makers to steer the European Green Deal towards a more egalitarian direction. ${ }^{14}$ The main subjects I identify as the recipients of egalitarian redistribution are workers, by which I broadly mean both employees and independent contractors who receive less income than owners of financial or physical capital. ${ }^{15}$ I do not mean to suggest that workers, and the discipline of labor law, are the only important locus of distributive concern; I merely follow the longstanding trend in modern progressive politics of seeing labor as a significant political actor and a relatively good proxy for the overall distribution of income and power in society. ${ }^{16}$

I focus my analysis on a specific type of environmental measure-regulations of permissible production techniques and taxes that raise the costs of production in traded-good sectors. I thus focus on production, as opposed to consumption, and on production of goods that are traded across Member-State borders. This allows me to hone in on a particular kind of distributive impact of environmental policy - the case where an environmental regulation raises the costs of production in both a lower-income, less competitive Member State and a higher-income, more-competitive one. If the regulation raises production costs to the same extent in both countries, the prevailing distribution of competitiveness - and therefore economic well-being ${ }^{17}$ — will be maintained. This outcome is problematic because, as I will argue, those who hold an egalitarian theory of justice and desert should deem the prevailing distribution of competitiveness and income between EU Member States unjust.

The other, perhaps more likely, outcome is that the environmental regulations and taxes are more burdensome to the lower-income, less-competitive countries because of their lesser ability to put in place greener production processes. In that case, environmental measures like many of those contemplated in the European Green Deal are likely to worsen inequalities in the European Union, thus running counter to the European Commission's stated intent. In order

EUROPEAN UNION 31, 32 (Jo Shaw ed., 2000) (arguing that the EU internal market has constrained "regulatory autonomy" in the fields of "labor law standards" and "environmental policy" alike).

${ }^{13}$ See, e.g., Brian Bercusson, Simon Deakin, Pertti Koistinen, Yota Kravaritou, Ulrich Muckeberger, Alain Supiot \& Bruno Veneziani, A Manifesto for Social Europe, 3 Eur. L.J. 189, 190 (1997); Neil Walker, The Place of European Law, in THE WORLDS of European Constitutionalism 57, 92-93 (Joseph Weiler \& Grainne de Búrca eds., 2011); Harm Schepel, Constitutionalising the Market, Marketising the Constitution, and to Tell the Difference: On the Horizontal Application of the Free Movement Provisions in EU Law, 18 EuR. L.J. 177, 178 (2012); Wolfgang Streeck, The Crises of Democratic Capitalism, 71 New LefT Rev. 5, 7 (2011).

${ }^{14}$ For the sake of argument and space constraints, I assume that a generally egalitarian normative agenda or social welfare function is accepted, and I do not make the case for it here. For a fuller argument in favor of such an agenda see Pascal McDougall, Capabilities, Utility, or Primary Goods? On Finding a Conceptual Framework for (International) Labour Law, in The Capabilities Approach To Labour Law 180, 192-201 (Brian Langille ed., 2019).

${ }^{15}$ In particular, small business owners operating with little physical and financial capital are analogous to workers, with the difference that they sell the product of their work directly to consumers without the intermediary of an employer. This analogy might underpin what has been called "petty bourgeois socialism," encompassing both small businesses and employees as against owners of financial and physical capital. See Cui Zhiyuan, China's Future: Suggestions from Petty Bourgeois Socialist Theories and Some Chinese Practices, in Contemporary Chinese Political Thought: Debates And Perspectives 209 (Fred Dallmayr \& Zhao Tingyang eds., 2012).

${ }^{16}$ For reflections on the conditions at which such a posture can be politically acceptable, see McDougall, supra note 14 , at $192-201$.

${ }^{17}$ See the caveat infra notes 181-82 and accompanying text as to the question of whether competitiveness and economic well-being always go hand in hand. 
to more clearly signal that the environment, labor, and "the market" are complex interlocking phenomena to be carefully articulated rather than put in binary opposition, I describe environmental regulatory costs as harms to labor rights. That is, I describe the pressure put by a regulation raising a lower-income-country firm's costs of production as an impairment of lower-incomecountry workers' "right to work" on the one hand or right to "fair wages" and "collective action" on the other, ${ }^{18}$ depending on whether the workers lose their jobs or accept cuts to (union-negotiated) wages because of the environmental regulation. This is not a claim for justiciable, legalistic sanctioning of labor rights violations per se. Rather, it is an argumentative move to emphasize that the costs imposed by environmental regulations in traded-good sectors are also injuries to workers, and not merely a matter of economic "efficiency" and performance in the abstract.

The overall goal of this Article is therefore to make the case that we should attend to the asymmetric impact of Green Deal and other environmental regulations on an already skewed distribution of welfare between workers and citizens in different EU Member States. The point is not that the benefits of environmental regulation should not be pursued; it is that the costs of pursuing these benefits can be shared in many different more or less egalitarian ways. In order to map these costs in the context of traded-good industries, this Article applies to trade law and economics a "legal institutionalist"19 approach that puts legal institutions at the heart of thinking about the economy. According to the legal institutionalist trade analysis developed here, competitiveness is not only a function of technological productivity and factor endowments as in traditional trade economics, ${ }^{20}$ but also of domestic legal institutions that shape the cost structures of traded-good production. Competitive advantage, absolute or comparative, is constructed by law. It is very often possible, then, for lower-income Member States to acquire new competitive advantages that will allow them to increase their workers' wages and be more resilient in the face of cost-increasing environmental regulations. State aid law should not stand in the way of domestic measures aiming to construct new competitive advantages - unless the redistribution that would result is deemed undesirable based on a normative theory of what EU-wide distribution of economic welfare is just. Such a theory-rather than simple claims that a given domestic measure "distorts" the marketshould be the focus of debates about what industrial policies EU Member States are allowed to pursue.

On the basis of this legal institutionalist view of the trade and labor impacts of environmental regulations, this Article puts forth ideas to pursue an ambitious EU-wide environmental transformation while also making progress towards remedying, or at the very least not worsening, inequalities in the EU. One important point is that lower-income EU Member States should be allowed to channel subsidies to their traded-good industries to neutralize the cost-increasing impact of certain Green Deal measures. This Article discusses various ways in which the costs of environmental regulations, and of subsidies that neutralize their impact on the welfare of workers, can be shifted to richer Member States so as to more effectively redistribute income in an egalitarian direction as part of the environmental transition. These ways of shifting the costs of subsidies include redistributive fiscal and monetary initiatives at the level of the EU, as well as making EU institutions the bodies that grant the subsidies. Given the hurdles to significantly increasing the budget and responsibilities of EU institutions even in the face of the current catastrophic pandemic and economic downturn, it seems more likely that actions to compensate the impact of the Green Deal on workers will be put in place at the national level. If that turns out to be the case, domestic state aid and subsidies will remain the central policy tools that would enable this Article's egalitarian agenda to be put in place. Finally, this Article also puts forth ideas for an egalitarian transition within richer Member States where job losses are incurred because of an EU-wide

\footnotetext{
${ }^{18}$ See infra Section B(III).

${ }^{19}$ See generally Simon Deakin, David Gindis, Geoffrey M. Hodgson, Huang Kainan \& Katharina Pistor, Legal Institutionalism: Capitalism and the Constitutive Role of Law, 45 J. COMP. ECON. 188 (2017).

${ }^{20}$ On these concepts and their traditional use, see infra note 148 and accompanying text.
} 
egalitarian redistribution of competitiveness. There, the focus can be on non-tradable sectors like green building renovation, urban infrastructure, and transport-perhaps as part of a state-led green local industrial policy to shift wealth to richer-country workers, even as some of their industries are overtaken by newly empowered poorer-country industries.

Such a targeted and differentiated approach to environmental policy-whereby sectors and regions are subject to different rules according to a broader social justice mandate and in which different groups of workers are seen as having conflicting interests-might be counterintuitive for environmental lawyers, as well as for EU social and labor lawyers. That said, this approach should be attractive to readers sympathetic to strands of critical legal studies that perform "distributive analysis" of legal rules, ${ }^{21}$ as well as to several currents of distribution-oriented environmental legal theory at the international level. ${ }^{22}$ This approach also fits well with trade law's longstanding recognition that certain industries sometimes need to be sacrificed to a broader trade agenda, and that the focus should be on making transition to new jobs and economic structures as painless as possible. ${ }^{23}$ Finally, such an approach is coherent with the European Green Deal itself. Not only is the latter explicitly framed as a "growth strategy," 24 terms which evoke conscious trade-offs and planning, but distributive issues are given a central place in the European Commission's proposed "just transition." 25 This Article, then, can be seen as an attempt to think more systematically about the implications of these existing aspects of the European Green Deal in light of the legal economics of trade, labor, and the environment.

The Article proceeds as follows. Section B(I) describes existing EU environmental rules that bear on the competitiveness of traded goods - the kind of measure on which I focus throughout. Section B(II) turns to describing how the European Green Deal proposes to modify existing rules of that kind. Section B(III) then lays out, using a very basic sketch of EU and Eurozone institutions, possible impacts of environmental regulations and taxes on the rights and welfare of workers in lower-income EU Member States. Part C contains the bulk of the Article's legal institutionalist approach to trade theory. Section C(I) provides some basic notions of EU state aid law that help contextualize more abstract economic theories on the causes of trade competitiveness, with special reference to the legality of granting subsidies to compensate for environmental regulatory cost increases. Section C(II) describes the pioneering contribution of trade law scholar Daniel Tarullo in applying legal institutionalism to trade issues. Section C(III) then draws some broader implications of the legal institutionalist analysis of competitiveness as legally constructed, emphasizing the ways in which new competitive advantages could be created in lowerincome Member States. Part D turns the focus back to environmental policy. Section D(I) reviews existing work incorporating distributive concerns into international environmental law and argues that the trade theory presented here makes such insights easier to integrate into EU law than the focus on post-colonial and post-imperial reparations one (rightly) finds at the international level. Section D(II) then reviews existing EU environmental rules specifically devised to reduce inequalities between workers in different Member States and formulates a few proposals

\footnotetext{
${ }^{21}$ See, e.g., Duncan Kennedy, Law and Economics from the Perspective of Critical Legal Studies, in THE NEw PALGRAVE Dictionary of Economics and THe LAW 465, 472-73 (Peter Newman ed., 1998); Aya Gruber, When Theory Met Practice: Distributional Analysis in Critical Criminal Law Theorizing, 83 FordHAM L. Rev. 3211, 3213-15 (2015).

${ }^{22}$ See infra Section $\mathrm{D}(\mathrm{I})$.

${ }^{23}$ See generally K.C. Fung \& Robert W. Staiger, Trade Liberalization and Trade Adjustment Assistance, in THE NEW Transatlantic Econ. 265 (Matthew B. Canzoneri, Wilfred J. Ethier \& Vittorio Grilli eds., 1996); Steve Charnovitz, Worker Adjustment: The Missing Ingredient in Trade Policy, (1986) CAL. MgMT. ReV. 157. See also Joost Pauwelyn, Recent Books on Trade and Environment: GATT Phantoms Still Haunt the WTO, 15 EUR. J. INT'L L. 575, 578 (2004) (providing a mainstream trade account of the variegated relationship between trade and the environment which is quite compatible with my approach)

${ }^{24}$ European Green Deal, supra note 1, at 2.

${ }^{25}$ See infra notes $188-90$ and accompanying text.
} 
to make this dimension more central to the European Green Deal and EU environmental policies more broadly.

\section{B. EU Environmental Law and the Problem of Trade Competitiveness}

\section{Existing EU Environmental Laws That Bear on Traded Goods}

Out of a panoply of measures proposed and already adopted to protect the environment in the EU, I focus here on a specific kind-those that raise the production costs of a traded good to the detriment of the trading partner that is less able to conform to the measure. I follow the traditional stylized legal and economic treatment of traded goods whereby imports into a country face an identical "import-competing" good. Each country, then, has domestic production competing with imports from abroad as well as exports competing with foreign goods abroad. ${ }^{26}$

The typical example of a measure that raises the production costs of a traded good to the detriment of one trading partner is a European directive uniformly banning a particular polluting production process. The result I focus on in this Article is that the cost-increasing measure has a disproportionate effect on one of the trading partners because of a lesser capacity to find an alternative production process that conforms to the regulation. If, on the contrary, the measure increases production costs equally for all trading partners, the relative trade volumes of the particular good will remain unchanged. ${ }^{27}$ This scenario is worrisome from the point of view of my legal institutionalist trade theory informed by an egalitarian normative agenda. But the worsening of current illegitimate inequalities in trade competitiveness is of course more preoccupying than the mere maintenance of such inequalities. There is in fact evidence that European countries differ greatly in their ability to comply with environmental regulation of production due to different levels of technological development ${ }^{28}$ which is plausibly correlated with national income as well as overall competitiveness of traded goods. ${ }^{29}$

There are many examples of existing legislative instruments that might lead to the imposition of such "hard" (and costly) regulatory limits on production processes. The REACH regulation banning certain chemical products that might be either produced or used in production is one example. ${ }^{30}$ We can also think of the EU directive on liability for environmental damage, which purports to bind Member States to impose remedial obligations on economic operators that cause such damage in the course of their productive activities. ${ }^{31}$ Another example is the Industrial Emissions Directive (IED), ${ }^{32}$ which applies to production above a certain volume in the energy

\footnotetext{
${ }^{26}$ See Wendy Carlin \& David Soskice, Macroeconomics and the Wage Bargain 223-28 (1990).

${ }^{27}$ The quantity sold will likely decrease everywhere as prices rise and consumers substitute into alternative goods. Still, there will be no substitution from the home traded good to the foreign identical traded good.

${ }^{28}$ See Kathryn Harrison \& Lisa McIntosh Sundstrom, The Comparative Politics of Climate Change, 7 GLOB. ENvTL. POL. 1, 4-5 (2007); Ludivine Tamiotti et al., Trade and Climate Change: A UneP-WTO Report 31 (2009); Intergovernmental Panel on Climate Change, Climate Change 2007: Mitigation of Climate Change 108-09 (Bert Metz et al. eds., 2007). There is also the different empirical finding that between 80 and $90 \%$ of investment in climate change mitigation technology is made, and the results patented-i.e. excluded from other countries-within the richer EU countries. See Francesco Pasimeni, Alessandro Fiorini \& Aliki Georgakaki, Assessing Private R\&D Spending in Europe for Climate Change Mitigation Technologies via Patent Data, 59 World Patent Information 1, 5 (2019). This could be explained by the fact that firms in richer European countries are simply more interested in protecting the environment. But it seems very plausible that unequal capabilities also have a bearing on this overwhelming disparity.

${ }^{29}$ On this correlation see Daniel Trefler, International Factor Price Differences: Leontief Was Right!, 101 J. POL. EcON. 961, 962 (1993); Irving B. Kravis \& Robert E. Lipsey, Toward an Explanation of National Price Levels 12-13 (1983).

${ }^{30}$ Commission Regulation 1907/2006/EC of Dec. 18, 2006, Concerning the Registration, Evaluation, Authorisation and Restriction of Chemicals (REACH), Establishing a European Chemicals Agency, 2006 O.J. (L 396) 1.

${ }^{31}$ Directive 2004/35, of the European Parliament and of the Council of 21 April 2004 on Environmental Liability with Regard to the Prevention and Remedying of Environmental Damage, art. 6(3), 2004 O.J. (L 143) 56.

${ }^{32}$ Directive 2010/75, of the European Parliament and of the Council of 24 November 2010 on Industrial Emissions (Integrated Pollution Prevention and Control), 2010 O.J. (L 334) 17.
} 
industries, the production and processing of metals, the mineral industry, the chemical industry, waste management, and other activities including industrial production of paper or cardboard and intensive rearing of poultry or pigs. ${ }^{33}$ Under the IED, Member States commit to issuing permits imposing conditions and limits on the emission of certain specified pollutants. ${ }^{34}$

Even relatively hard instruments such as the Industrial Emissions Directive nevertheless show that an environmental measure's "hardness" is always a matter of degree. The Directive imposes, inter alia, obligations "that all the appropriate preventive measures [be] taken against pollution" and that "the best available techniques" be applied. ${ }^{35} \mathrm{EU}$ and national expert bodies conduct economic and scientific analyses to determine which production techniques offer the most environmental benefits for any given economic cost_an inquiry which is then to inform Member States' imposition of conditions in the permits they grant. ${ }^{36}$ Such broad standards and balancing exercises can be found in several other regulations including the Air Quality Directive, which mandates certain measures to impede the emission of pollutants "where possible" and barring "disproportionate costs." "That said, however indeterminate these standards might be, they remain hard compared to "framework" directives that merely provide for information and expertise sharing instead of substantive obligations on states and private actors. ${ }^{38}$ It is said that as the EU has come to encompass nations with ever-lower national incomes, EU environmental law has shifted to ever-softer regulations in the sense of not imposing substantive standards. ${ }^{39}$

Often, then, prohibitions of certain production processes are subject to qualifiers or inevitably vague terms that need to be further interpreted and applied to any given production process and specific factual context. At other times, there may not even be a substantive prohibition but merely a procedural venue in which policies must be discussed and justified. This undoubtedly renders EU environmental law in many cases less constraining than what would be desirable from an environmental perspective. It seems implausible, however, that this body of law never leads a firm to abandon a production process. Whenever it is the case that a soft information-sharing procedure, a diffuse standard like "best available technique," or a harder prohibition leads a firm to replace a production process with another more eco-friendly and costly one, the phenomenon I study in this Article is present. Moreover, because I am assessing the potential impact of a radical scaling up of these measures which the Green Deal promises, I contemplate in this Article a scenario in which this policy plan is in fact successfully put into place and in which many polluting production processes are abandoned because of EU regulations. If this scenario does not materialize, the Green Deal will have failed and this Article will lose much of its relevance.

So far, I have mentioned regulations that prohibit-using more or less soft means and more or less precise language - certain production processes. But rather than an outright prohibition, the

\footnotetext{
${ }^{33} I d$. annex I.

${ }^{34} I d$. annex II.

${ }^{35}$ Id. art. 11.

${ }^{36}$ See Maria Lee, EU Environmental Law, Governance and Decision-Making 112 (2d ed. 2014).

${ }^{37}$ Directive 2008/50, of the European Parliament and of the Council of 21 May 2008 on Ambient Air Quality and Cleaner Air for Europe, art. 2(9), 17(1), 2008 O.J. (L 152) 1. See Mark Wilde, The New Directive on Ambient Air Quality and Cleaner Air for Europe, 12 ENVTL. L. ReV. 283, 285 (2017).

${ }^{38}$ See, e.g., Directive 2000/60, of the European Parliament and of the Council of 23 October 2000 Establishing a Framework for Community Action in the Field of Water Policy, 2000 O.J. (L 327) 1 (giving guidance and procedural avenues to national authorities and private stakeholders without imposing substantive standards beyond that of having "good water status"). For a description of the directive and its institutional context see Blandine Boeuf \& Oliver Fritsch, Studying the Implementation of the Water Framework Directive in Europe: A Meta-Analysis of 89 Journal Articles, 21:2 Ecology \& Soc'Y (2016). On framework directives as "soft" EU environmental law see Ingmar von Homeyer, The Evolution of EU Environmental Governance, in Environmental Protection: European Law and Governance 1, 17 (Joanne Scott ed., 2009).

${ }^{39}$ See Homeyer, supra note 38, at 20; NicOlas DE SADELEER, EU ENVIrONMENTAL LAW AND THE INTERNAL MARKET 207-08 (2014). On the different kinds of "soft" modes of environmental regulation, see Helle Tegner Anker, Competences for EU Environmental Legislation: About Blurry Boundaries and Ample Opportunities, in RESEARCH HANDBOOK ON EU Environmental Law 7, 10 (Marjan Peeters \& Mariolina Eliantonio eds., 2020).
} 
instrument used can be a tax on the pollution emitted by the production processes in question. The EU Emissions Trading Scheme (ETS), introduced in 2005, is an example of such an approach. ${ }^{40}$ Under "cap-and-trade" systems like the ETS, the state sets a cap on certain greenhouse gas emissions and sells a finite number of emission allowances that can then be sold off to the highest bidder. ${ }^{41}$ The environmental protection effect comes from the cap and from the need to pay the tax (buy the allowance) in order to emit certain greenhouse gases-which together operate to curtail pollution by forcing firms as a whole to either limit production or find alternative production processes, in the latter case likely at a higher cost, which will also limit production. $^{42}$

The fact that under cap-and-trade systems governments tax production-through the proxy of pollution-instead of banning production techniques gives revenue to the governments issuing the pollution allowances. ${ }^{43}$ That said, the EU ETS allowances have so far mostly been given away instead of being auctioned. ${ }^{44}$ Moreover, the ETS only covers certain sectors, ${ }^{45}$ and the cap on emissions was initially set at a level so high that its impact in pressuring production costs and pollution was probably nonexistent. ${ }^{46}$ But the cap has been repeatedly lowered, and the EU has moved towards auctioning more and more allowances, instead of giving them away, as the years have passed. ${ }^{47}$ The EU has also repeatedly intervened to raise the market price of ETS allowances. ${ }^{48}$ To the extent the cap becomes binding on a sector and forces firms to buy allowances from either the state or another firm - and accordingly raise their product prices because of higher production costs-the phenomenon I study in this Article is present.

Thus far I have only dealt with measures taken by EU institutions. Member States can also adopt measures that have the impact of raising production costs in traded-good sectors. ${ }^{49}$ Usually, the scenario is one in which a Member State applies a domestic environmental measure which its import-competing-good producers can more easily conform to than foreign producers selling imports into the Member State. ${ }^{50}$ The distinction between measures taken by EU institutions and measures taken by Member States is, however, blurred most of the time. This is because most EU directives are implemented by Member States enacting their own regulations. ${ }^{51}$ There is

\footnotetext{
${ }^{40}$ See Directive 2003/87, of the European Parliament and of the Council of 13 October 2003 Establishing a Scheme for Greenhouse Gas Emission Allowance Trading Within the Community and Amending Council Directive 96/61/EC, 2003 O.J. (L 275) 32.

${ }^{41}$ See Daniel H. Cole, Origins of Emissions Trading in Theory and Early Practice, in RESEARCH HaNDBOOK ON EMISSIONS Trading 9, 9-10 (Stefan E. Weishaar ed., 2016).

${ }^{42}$ In fact, if the cap is binding, the existence or absence of an initial tax should not matter; the permit will have value by the mere fact of its scarcity. See Robert Stavins, Market-Based Environmental Policies: What Can We Learn from U.S. Experience (and Related Research)?, in Moving to Markets in EnVironmental Regulation: Lessons from Twenty Years of EXPERIENCE 19, 26-27 (Jody Freeman \& Charles D. Kolstad eds., 2007).

${ }^{43} I d$.

${ }^{44}$ See David Langlet \& Said Mahmoudi, EU Environmental Law and Policy 260 (2016).

${ }^{45}$ See EU Emissions Trading System (EU ETS), EUR. COMM'N, https://ec.europa.eu/clima/policies/ets_en (last visited July 17, 2020).

${ }^{46}$ See LANGLET \& MAHMOUdi, supra note 44, at 261.

${ }^{47}$ European Commission, supra note 45.

${ }^{48}$ See LANGLet \& Mahmoudi, supra note 44 , at 261.

${ }^{49}$ See, e.g., Case 302/86, Commission v. Denmark, 1988 E.C.R. 4607, on a measure imposing the use of recyclable materials which the complainant foreign producers were apparently less capable of using than domestic import-competing producers.

${ }^{50}$ See id. It of course occurs more rarely that a Member State imposes a norm which disadvantages its import-competing producers, or its exporters vis-à-vis foreign producers competing with its exports.

${ }^{51}$ See, e.g., Case C-309/02, Radberger Getränkegesellschaft, E.C.R. 2004 I-11763, para. 9 (involving a foreign producer challenging a German law implementing a European directive that limited wasteful packaging — for instance by imposing that sellers accept and allow customers, at no charge, to return the package for recycling). For an example of a yet more decentralized regulation, see ECJ, Case C-573/12, Alands Vindkraft, ECLI:EU:C:2014:2037, Judgement of July 1, 2014, http://curia. europa.eu/juris/liste.jsf?num=C-573/12\&language $=\mathrm{EN}$ (dealing with EU directives on renewable energy and national measures taken to implement those).
} 
also the question of whether a Member State can act above and beyond the requirements for implementing an EU environmental legislative act. This is impossible if the act provides for "total harmonization" as opposed to merely setting minimum standards that leave Member States free to enact higher environmental norms - subject of course to conformity with Treaty rules on freedom of movement if a foreign producer challenges the importing state's measure. ${ }^{52}$ As with EU-level regulations, the precise extent to which production costs are raised may not be known in advance and may depend on the application of loose standards like "appropriate" or "proportionate." Additional, typically judicial, complexities intervene, as in the case where an environmental measure targeting foreign traded goods is justified only if it gives producers a reasonable transition period before it applies to them. ${ }^{53}$

\section{The Proposed European Green Deal and Its Trade-Relevant Measures}

The institutions and rules described in subsection (I) all existed prior to the Green Deal as announced by the European Commission in late 2019. The Green Deal is in fact best seen not as a separate set of policies, but as a programmatic statement announcing the scaling up of existing rules just as much as the adoption of new ones. References to the Green Deal must thus also be taken to be references to the broader and largely preexisting European environmental agenda of which it is a part. I now look at a few of the reinforcements the Green Deal proposes to apply to the kind of traded-good-cost-increasing measure I focus on in this Article.

The Green Deal mentions extensions of the EU Emissions Trading Scheme to new sectors, with maritime and road transport being singled out as targets, ${ }^{54}$ to "ensure effective carbon pricing throughout the economy." 55 Given the extent to which traded goods rely on road transport, this will raise the final price of many such goods. The Commission also states its intent to reduce the airline sector's free ETS allowances, and to impose more stringent air-pollutant-emission standards for combustion-engine vehicles. ${ }^{56}$ The Commission further mentions the "decarbonization and modernization" of industries producing steel, chemicals, and cement, which in turn are used as inputs in many other industries in the EU. ${ }^{57}$ For further information on what it means by that, the Commission refers to a 2019 report by Member States, industry, and civil society outlining many possible changes to the production processes of those inputs, including cutting out more polluting steps in the processes and recycling or neutralizing the waste generated by this production. ${ }^{58}$ The potential breadth of these measures is impressive, although as with all broad policy announcements, the devil will be in the details of the implementation still to come.

In addition, the Green Deal contains a "circular economy action plan," which will impose further prohibitions and obligations related to the packaging of products and the possibility for consumers to have their package reused or recycled at a cost to the producer. ${ }^{59}$ The Commission further mentions a specific target for regulation, the use of "microplastics" in products, and the "unintentional releases of plastics, for example from textiles and tyre abrasion." ${ }^{\circ 0}$ It also promises to present a comprehensive "chemicals strategy for sustainability" further limiting the use of

\footnotetext{
${ }^{52}$ See Charles Poncelet, Free Movement of Goods and Environmental Protection in EU Law: A Troubled Relationship?, 15 INT'L CMTy. L. REV. 171, 182-83 (2013).

${ }^{53}$ See Radberger Getränkegesellschaft, supra note 51, para. 81.

${ }^{54}$ European Green Deal, supra note 1, at 11.

${ }^{55} \mathrm{Id}$. at 5 .

${ }^{56} I d$. at 11 .

${ }^{57} \mathrm{Id}$. at 7.

${ }^{58}$ See High-Level Group on Energy-intensive Industries, Masterplan for a Competitive Transformation of EU Energy-intensive Industries Enabling a Climate-neutral, Circular Economy by 2050, at 26 (2019), https://ec.europa.eu/docsroom/ documents/38403.

${ }^{59}$ European Green Deal, supra note 1 , at 7.

${ }^{60} I d$. at $7-8$.
} 
certain chemical substances in products and production processes. ${ }^{61}$ Finally, as part of the "food to fork" agricultural strategy, the Commission wants to establish national action plans with Member States that "will need to reflect an increased level of ambition to reduce significantly the use and risk of chemical pesticides, as well as the use of fertilisers and antibiotics." ${ }^{2}$ These substances are plausibly used only because they lower production costs.

These are just a few examples of the measures contemplated which seem likely to lead to regulatory prohibitions and taxes that will increase the costs of production of traded goods as described above. The Commission also alludes to other measures that shift the costs of the greening of any given traded good away from the producer of the good. For instance, on transport, it states its intent to adopt "measures" to "increase the capacity of railways and inland waterways" 63 and "boost the production and uptake of sustainable alternative fuels for the different transport modes" 64 - terms that seem to point in the direction of European subsidies. The Commission also states that the "EU budget will play a key role" in the Green Deal, and the new revenue sources it mentions for this purpose are the tax on plastic waste currently being negotiated ${ }^{65}$ and the tax from those Emissions Trading Scheme allowances that are initially auctioned, as opposed to handed out for free. ${ }^{66}$

To the extent that these environmental taxes fall on other traded goods produced in the Member State in which the subsidized traded-good producer is located, that state will get less net overall benefit from the subsidy, although that scenario is preferable to a tax or cost-raising regulation and no EU subsidy at all. Conversely, if EU subsidies come from revenue sources outside the Member State of the producer that is subsidized into greener production, that Member State is a net winner. This outcome can be brought about by the normal operation of EU fiscal rules, whereby richer and more environmentally performing states contribute a greater proportion of revenues, ${ }^{67}$ or by the operation of eventual EU common fiscal instruments. ${ }^{68}$ As mentioned in the previous paragraph, however, the new sources of revenue the Commission plans to use to finance the Green Deal's EU-level subsidies are mostly environmental taxes, and not the progressive fiscal measures just mentioned. It therefore seems unlikely that the Green Deal's EU-level subsidies will accomplish much progressive redistribution or compensation for the impact of regulatory prohibitions on lower-income EU countries.

The Commission also mentions loans from the European Investment Bank (EIB) and changes to EU financial regulation to steer private finance in the direction of green lending. ${ }^{69}$ Finally, it mentions making changes to the EU rules on Member State fiscal spending, ${ }^{70}$ and we might also include European Central Bank policies that condition Member States' access to revenue more generally. I forego a detailed analysis of these monetary conduits in this Article, ${ }^{71}$ because

\footnotetext{
${ }^{61} I d$. at 15.

${ }^{62} I d$. at 12 .

${ }^{63} \mathrm{Id}$. at 11 .

${ }^{64} I d$. at 11 .

${ }^{65} \mathrm{Id}$. at 15 . For the initial proposal for a plastic waste tax, see Proposal for a Council Decision on the System of Own Resources of the European Union, at section 1.3, COM (2018) 325 final (May 2, 2018).

${ }^{66}$ European Green Deal, supra note 1, at 15. The Commission also mentions that the EU budget will be mobilized on the spending side, as opposed to the revenue side, through "mainstreaming" of environmental goals in existing EU spending. Id.

${ }^{67} \mathrm{On}$ the make-up of EU revenues, see EU Budget for the Future: Modernising the EU Budget's Revenue Side, EUR. COMm’N https://ec.europa.eu/commission/sites/beta-political/files/budget-proposals-modernising-budget-revenue-side-may2018_ en.pdf (last visited July 17, 2020).

${ }^{68} \mathrm{On}$ the role of an EU common debt instrument in reducing the borrowing costs of some Member States by pooling risk, see Thomas Eger \& Hans-Bernd Schäfer, Introduction: Eurobonds Beyond Crisis Management, 12 REV. L. \& ECON. 477, 485-86 (2016).

${ }^{69}$ European Green Deal, supra note 1, at 16-17.

${ }^{70} I d$. at 17 .

${ }^{71}$ On the impact of central bank policies on the differentiated fiscal space of Member States, see Isabel Feichtner, Public Law's Rationalization of the Legal Architecture of Money: What Might Legal Analysis of Money Become?, 17 GERMAN L.J. 875,
} 
I am mainly concerned with mapping the international trade impact of cost-raising regulations and taxes on the welfare of poorer EU Member States. The main remedy I propose is to neutralize the competitiveness-reducing impact of environmental regulations, and to, broadly speaking, transfer money to pay for the measures that neutralize the competitiveness reduction. The further exploration of concrete ways in which this transfer might be achieved will require delving into the monetary institutional design that conditions fiscal space and monetary autonomy in the EU.

\section{The Impact of Environmental Regulations on Workers' Rights}

In this subsection I present a sketch of the effect we can expect production-cost-raising environmental regulations to have on workers' rights and welfare, under different assumptions about the background of monetary institutions. Because more or less competitive imports and exports have a significant impact on the country through the balance of payments and the monetary institutions that structure it, these institutions cannot be left out of an analysis of the effect of competitiveness-decreasing environmental measures on a country and its workers. As mentioned above, I briefly mention a few labor rights not in the spirit of making justiciable or legalistic claims but rather to emphasize the legal and political interests that are at stake.

The first possible impact of stricter environmental measures affecting a country's traded-good competitiveness is that workers accept a wage decrease that fully offsets the added regulatory cost. So, for instance, exporting firms having seen their production costs rise by more than those of foreign firms competing with their goods abroad can ask their employees to reduce wages to avoid losing sales and cutting jobs. If the employees reduce their wages enough, the exporting firms can bring their total production costs back to their previous ratio to those of the foreign firms. In that case, the only labor right potentially infringed is that to "fair and just working conditions"72 or "fair wages that provide for a decent standard of living." ${ }^{\prime 3}$ Alternatively, the right infringed may be that "wages ... be set ... respecting the autonomy of the social partners"74 and "the right to collective action,"75 if environmental regulations constrain workers to forego union-negotiated wage increases.

The more complex case is where workers do not accept a wage decrease that fully offsets the regulatory cost. If not many firms are concerned, the only repercussion might be that there are some lost sales and that some workers lose their jobs due to downsizing. Relative to the scenario in which no environmental regulation is imposed, workers' "right to work" is arguably compromised. ${ }^{76}$ If a sizeable number of firms are covered by such regulations - which seems required to reach the Green Deal's environmental ambitions - and if the firms are not able to reduce wages enough, the impact of less-competitive traded goods will be felt across the economy. There will be fewer exports (as foreign consumers shift to now less-expensive foreign goods competing with home exports abroad) or more imports (as home consumers shift from home import-competing

896 (2016); Daniela Gabor \& Cornel Ban, Banking on Bonds: The New Links Between States and Markets, 54 J. CoM. MKT. STUD. 617, 624-25 (2016). On the mechanics and distributive impact of using central bank and macro-prudential regulation to stimulate green investment, see Daniela Gabor, Three Myths About EU's Economic Response To The Covid19 Pandemic, Critical Macro Fin. (June 17, 2020), https://criticalfinance.org/2020/06/17/three-myths-about-eus-economic-responseto-the-covid19-pandemic/.

${ }^{72}$ Charter of Fundamental Rights of the European Union, art. 31, Oct. 26, 2012, 2012 O.J. (C 326) 391.

${ }^{73}$ Recommendation on the European Pillar of Social Rights, at principle 6, COM (2017) 2600 final (Apr. 26, 2017).

${ }^{74} \mathrm{Id}$.

${ }^{75} \mathrm{Id}$. at principle 8.

${ }^{76}$ G.A. Res. 2200A (XXI), International Covenant on Economic, Social and Cultural Rights, art. 6, (Dec. 16, 1966), 993 U.N.T.S. 3; Council of Europe, European Social Charter (REvised) of 1966, art. 1(1) (1996), https://www.coe.int/ en/web/conventions/full-list/-/conventions/treaty/163. On the interpretation of the scope of states' obligations under the European Social Charter's right to work, including setting up active employment policies and job creation schemes, see Colm O'Cinneide, The Right to Work in International Human Rights Law, in ThE Right TO WORK: LEGAL AND Philosophical Perspectives 99, 114-15 (Virginia Mantouvalou ed., 2015). 
goods to imports), depending on whether the domestic firms in question are in the export or import-competing sector. If enough firms are covered by these pressures, this will push the country in question towards a trade deficit, which the lower-income Member States of the European East and South have already long tended to have. ${ }^{77}$

What happens next depends on what the exchange rate regime is assumed to be. A trade deficit by a nation having its own currency usually cannot be sustained indefinitely, as there is insufficient demand for the deficit-country currency, which causes downward pressure on its value. ${ }^{78}$ Under a "pure" floating exchange rate, countries by definition always eliminate trade deficits by allowing their currencies to depreciate, which, assuming product prices are temporarily fixed, makes exports and import-competing goods cheaper than the goods sold by competitors. ${ }^{79}$ That said, by allowing its currency to depreciate, the country is depriving itself of cheaper imports. Even if export and import-competing sales rise by an amount greater than that by which the value of the remaining imports rises, ${ }^{80}$ the fact remains that depreciation makes prices go up for some importers. If those importers are workers, or industries that hire workers, depreciation does not fully eliminate the impairment of the rights of workers imposed by the environmental regulation. Additionally, if the country in question has incurred debt denominated in a foreign currency, depreciating the currency will raise the foreign debt burden and hurt the country as a whole, and therefore likely its workers as well. ${ }^{81}$

If the country in question wants to maintain a fixed exchange rate, or a managed float, at the level at which by hypothesis domestic goods are not competitive enough to have a balanced current account, the country can undergo a so-called "internal devaluation." 82 This entails a lowering of the domestic price level enacted through "austerity" measures of fiscal and monetary contraction, so that domestic goods regain their competitiveness despite the unchanged nominal exchange rate. ${ }^{83}$ If this generalized price drop could happen all at once with no lasting recessionary effect, internal devaluation would inflict only the same loss as that caused by nominal exchange rate depreciation as described in the previous paragraph. If internal devaluation does cause a recession because of non-simultaneity in price drops causing bankruptcies, ${ }^{84}$ workers' wages and jobs will be compromised throughout the domestic economy. ${ }^{85}$ As an alternative to internal devaluation, the country in question can use its reserves of foreign currency to buy its own currency in order to keep its value, and the prevailing nominal exchange rate, up. ${ }^{86}$ This latter solution, of course, can only last as long as the country has foreign exchange reserves. As already suggested, the dilemmas outlined in this paragraph and the previous one apply just as well to

\footnotetext{
${ }^{77}$ See Euro Area International Trade in Goods Surplus $€ 2.9$ BN, EUROSTAT (Nov. 13, 2020), https://trade.ec.europa.eu/ doclib/docs/2013/december/tradoc_151969.pdf.

${ }^{78}$ See William A. McEachern, Macroeconomics: A Contemporary Introduction 421-22 (2009).

${ }^{79} \mathrm{Id}$. at $417-18$.

${ }^{80}$ This is referred to as the Marshall-Lerner conditions, which are necessary for a depreciation to improve the trade balance at all. Even if the Marshall-Lerner conditions are satisfied and the trade balance on net improves, there remains an increase in import prices. See Robert Carbaugh, InTERnational ECONOMics 449-51 (12th ed. 2009).

${ }^{81}$ See Barry Eichengreen, Ricardo Hausmann \& Ugo Panizza, Currency Mismatches, Debt Intolerance and Original Sin: Why They Are Not the Same and Why it Matters, in Capital Controls and Capital Flows in EMERging ECONOMIEs: Policies, Practices And Consequences 121, 125 (Sebastian Edwards ed., 2007).

${ }^{82}$ See Paul De Graune, Economics of Monetary Union 139 (11th ed. 2016).

${ }^{83} \mathrm{Id}$.

${ }^{84}$ On these dynamics see Barry Eichengreen, Globalizing Capital: A History of the International Monetary SYSTEM 25-28 (2d ed. 2008).

${ }^{85}$ See Adam Harmes, Institutional Investors and Polanyi's Double Movement: A Model of Contemporary Currency Crises, 8 REV. INT'L POL. ECON. 389, 402 (2001).

${ }^{86}$ See MCEACHERN, supra note 78, at 421. I speak of an exchange rate being "high" or kept "up" when the currency I am talking about is appreciated. Thus, the currency I am talking about is the denominator, and the other currency is the numerator. This is contrary to the most common usage in which an appreciated currency amounts to a "low" exchange rate, which I find less intuitive. See id. at 416.
} 
EU Member States on a fixed exchange rate (e.g. Bulgaria, Croatia) wondering whether to devalue their currency as it does to Member States on a floating exchange rate (e.g. Romania, Hungary) wondering whether to manage the float so that the exchange rate stays high instead of depreciating.

Many countries in the EU do not have their own currency but share one with some of their European trading partners - the Euro. Under a common currency, the pressure to adjust and eliminate the trade deficit does not come from the channel identified above for independent currencies, whereby a state runs out of foreign reserves it had used to keep the value of its currency up and is thereby constrained to devalue its currency. Instead, in a currency area the pressure comes from investors who fear an exit of the country of which they hold the sovereign debt instruments. The investors then ask for a higher interest rate in exchange for holding the Member State's debt instruments, known in Europe as the "spread" between the interest rate on a country's bonds and that on German bonds. ${ }^{87}$ This raises the cost of borrowing for the state concerned. It also opens the door to "self-fulfilling" sales of sovereign debt instruments that raise the interest rate to such an extent that domestic debt that was otherwise sustainable might become unsustainable by the mere fact that investors are selling the debt instruments in question. ${ }^{88}$ The interest rate increases can prompt a debt crisis and force an exit from the currency area.

That said, why would investors calculate that a Member State's exit from the currency area is ever likely to start with, given that members of a common currency area do not face the pressure of running out of reserves of the currency used by their main trading partners? The answer is that mechanisms other than needing foreign reserves can render a trade deficit unsustainable in a currency area. In particular, if a country wants to sustain a trade deficit-in other words buy more than the total value of what it is producing - there must be an additional injection of income into the economy. To put it crudely, the importers need to get the money to buy their goods from somewhere other than from income generated by existing national production. The sources usually identified as allowing for this spending beyond national income are fiscal deficits generating income through a fiscal multiplier ${ }^{89}$ and monetary expansion (loans) by domestic or foreign banks. ${ }^{90}$ If there is a large and lasting trade deficit, then, it is likely financed through debt which can potentially become unsustainable, particularly if there are "self-fulfilling" runs on bond markets as described in the previous paragraph. The risk perceived by holders of public debt instruments is then not only one of exit, but also one of default on public debt. This can occur even if the trade deficit is initially entirely financed by private indebtedness, as firms and households taking on excessive debt can go bankrupt and become fiscal burdens on the state, along with any domestic banks on whose loans they default. ${ }^{91}$ This is how trade deficits can endanger a state's ability to remain in a common currency area.

The benefits of exiting a common currency area are that in addition to defaulting on its unsustainable debt, the country in question can boost its export and import-competing sales by having a new currency that trades with the common currency at a lower rate. ${ }^{92}$ This allows the country to have less of a trade deficit with the other countries from the start. There are of course massive costs to exiting - including capital flight and retaliation by investors asking higher interest rates in the

\footnotetext{
${ }^{87}$ See Gabor \& Ban, supra note 71, at 629-31.

${ }^{88}$ On self-fulfilling runs on bond markets, see Paul De Grauwe, The European Central Bank as Lender of Last Resort in Government Bond Markets, 59 CESIFO ECON. STUD. 520, 521-22 (2013). On self-fulfilling crises involving an autonomous currency instead of a state's public debt under a common currency, see Maurice Obstfeld, Models of Currency Crises With Selffulfilling Features, 40 EUR. ECON. ReV. 1037, 1039-41 (1996).

${ }^{89}$ See Paul Krugman \& Maurice Obstfeld, International Economics: Theory and Policy 446 (8th ed. 2009).

${ }^{90}$ See Jeffry A. Frieden, Currency Politics: The Political Economy of Exchange Rate Policy 3-4, 21 (2015).

${ }^{91}$ See Philip Lane, The European Sovereign Debt Crisis, 26 J. ECON. PersP. 49, 55 (2012); Hans-Werner Sinn, The Euro Trap: On Bursting Bubbles, Budgets, And Beliefs 41 (2014).

${ }^{92}$ See De Grauwe, supra note 82 , at $122-23$.
} 
future..$^{93}$ There is no need to exit or devalue, and the same re-equilibration of the current account can occur with some combination of sovereign debt default and targeted rescue by the common currency area's central bank. ${ }^{94}$ Any "forced" exit, then, would be caused by the central authorities' unwillingness to restructure the imbalances while maintaining the common currency and the implicit fixed exchange rate it furnishes the Member States. If the debt restructuring and central authority aid that is offered is conditioned on "austerity" reforms that have the effect of significantly depressing the deficit economies, the disruptions of exiting the common currency area might then become a more attractive alternative.

I am now contemplating a perhaps dramatic scenario in which the workers in the traded-good industries affected by the cost-increasing environmental regulations do not accept a sufficient wage decrease, in which a common currency prevents depreciation from neutralizing the competitiveness-reducing effects of the regulations, and in which the trade deficit is significant enough in magnitude that it raises the cost of the Member State's sovereign debt. It is unlikely that environmental regulations alone can cause a trade deficit important enough to bring these results about. That said, the whole of the Eurozone periphery has been undergoing massive trade deficits that were arguably at the heart of the debt crises of the last decade and of ongoing fiscal and monetary troubles. Therefore, I feel justified in contemplating the scenario in which ambitious environmental regulation worsens an already precarious fiscal and commercial balance in the Eurozone periphery. In this scenario, it bears notice that the rights and interests of workers are affected through many channels other than merely that of having to accept lower wages or job losses in the industry targeted by the environmental regulation. Here, workers outside tradedgood sectors are also affected. A higher borrowing cost, and no sovereign control over the central bank, will diminish the ability of the state to fund worker benefits without taxing citizens who might happen to be workers. And a debt crisis can lead to large-scale restrictions on the right to work and to fair wages/collective action as economic activity plummets and firms close. ${ }^{95}$ In all these scenarios, from the more modest to the more dramatic, workers would be prejudiced by environmental regulations that significantly raised production costs in traded-good industries.

\section{The Legal Structure of Trade Competitiveness}

If environmental production-cost-increasing measures, provided they are widely applicable enough, can cause such damage to labor rights and interests, one might ask whether a Member State can do anything to increase the competitiveness of its traded-good industries to avoid these detrimental impacts. The simplest thing we can imagine doing is compensating with monetary grants the entire amount of the environmental measure's cost increase. More subtle policies include building infrastructure, investing in employee training, and giving firms access to more financial capital — through development-bank lending or outright fiscal grants—so that they can increase their stock of physical capital and their productivity. ${ }^{96}$ These more subtle policies would have the same effect as a direct compensation, i.e. making the recipient firms better able to shoulder the added environmental regulatory costs.

EU state aid law determines which policies states are authorized to adopt in order to increase the competitiveness of their industries. In addition to settling the question of the legality of any given policy, state aid law also gives institutional and legal content to abstract economic concepts

\footnotetext{
${ }^{93}$ See generally Hal Scott, When the Euro Falls Apart - A Sequel (Harvard Pub. Law Working Paper No. 12-16, 2012).

${ }^{94} I d$. The analogy would be to the methods of sharing the burden of adjustment while limiting devaluation under the "snake in the tunnel" and European Monetary System regimes that preceded the Euro. See Horst Ungerer, A CONCISE History OF European MONETARY INTEgRation 188-90 (1997).

${ }^{95}$ See Aristea Koukiadaki, The Legacy of the Economic Crisis for Labour Law in Europe, in RESEARCH HANDBOOK ON EU Labour Law 64, 79 (Alan Bogg, Cathryn Costello \& A.C.L. Davies eds., 2016).

${ }^{96}$ On the latter phenomenon see Walter Nicholson, Microeconomic Theory: BAsic Principles and Extensions 63640 (2002).
} 
like "productivity" and "factor endowments" that, according to standard economic theory, determine which country can trade which good at what price. ${ }^{97}$ In that sense, the technicalities of state aid law are indispensable for any discussion of the way in which the asymmetrical vulnerability to the labor right harms described in Section $\mathrm{B}$ (III) is constituted and might be modified in a common market like the EU. I therefore provide in Section C(I) an overview of the relevant EU state aid notions before presenting in Sections C(II) and C(III) an institutionalist approach that puts state aid legal questions at the heart of economic theories of free trade, with wide-ranging implications for the array of policies that could be adopted under the European Green Deal.

\section{Some EU State Aid Basics}

Article $107(1)$ of the Treaty on the Functioning of the European Union ${ }^{98}$ lays out the basic prohibition on illegal state aid defined as (1) an economic advantage, (2) conferred by a Member State or through State resources, which (3) distorts or threatens to distort competition in a way that (4) affects trade between Member States. ${ }^{99}$ The criterion of economic advantage, whereby it is assessed "whether the recipient undertaking receives an economic advantage which it would not have obtained under normal market conditions," 100 is the main focus of the state aid inquiry. Indeed, it is said that the distortion of competition criterion is often conflated with that of the presence of an economic advantage beyond that which would be obtained in a normal market. ${ }^{101}$

The condition of "selectivity," as opposed to "generality," often turns out to be a central component of the advantage criterion. ${ }^{102}$ The prototypical example of a general measure is one that applies to all the firms in a Member State. ${ }^{103}$ "General infrastructure" and "non-sectoral measures of general taxation policy" are examples of such non-specific measures. ${ }^{104}$ That said, even measures that are generally available can be found to be selective if only certain firms use them. ${ }^{105}$ This is referred to as de facto, as opposed to de jure, selectivity. ${ }^{106}$ More generally, a measure can be found not to be selective if it applies only to firms that are in a similar "legal and factual situation," 107 or that are "in a position to use" the aid. ${ }^{108}$ It is sometimes added that even a prima facie selective measure can be legal if the selectivity flows from the "internal logic" of or is "inherent" to the legislative "system" of which the measure is part—examples of this sometimes given are progressive taxation and, notably, exemptions from charges based on environmental considerations. ${ }^{109}$

\footnotetext{
${ }^{97}$ On these concepts see infra note 148 and accompanying text.

${ }^{98}$ Treaty on the Functioning of the European Union, art. 107(1), Oct. 26, 2012, 2012 O.J. (C 326) 1 [hereinafter TFEU].

${ }^{99}$ See Paul Craig \& Grainne De Burca, EU law: Text, Cases, and Materials 1133 (2015).

${ }^{100}$ Case C-39/94, Syndicat français de l'Express international (SFEI) and others v. La Poste and Others, 1996 E.C.R. I-3547, para. 60 [hereinafter SFEI].

${ }^{101}$ Craig \& DE BurCa, supra note 99 , at 1138.

${ }^{102}$ It is said that the European Court of Justice tends to treat selectivity as part of the advantage inquiry, whereas the Commission treats selectivity as a separate criterion in itself. See Kelyn Bacon, European Union Law of State Aid 69 n.485 (3d ed. 2017).

${ }^{103} I d$. at 77 .

${ }^{104}$ CRAIG \& De BURCA, supra note 99, at 1134.

${ }^{105}$ See BACON, supra note 102 , at 21.

${ }^{106}$ Commission Notice on the Notion of State Aid as Referred to in Article 107(1) of the Treaty on the Functioning of the European Union, 2016 O.J. (C 262), 1, 28 [hereinafter Commission State Aid Notice].

${ }^{107}$ Julie Bousin \& Jorge Piernas, Developments in the Notion of Selectivity, 7 Euro. STATE Aid L. 634,640 (2008).

${ }^{108}$ BACON, supra note 102 , at 78 .

${ }^{109}$ Case C-143/99, Adria-Wien Pipeline $\mathrm{GmbH}$ and Wietersdörfer \& Peggauer Zementwerke GmbH v. Finanzalandesdirektion für Kärnten, 2001 E.C.R. I-8365, para. 42; Commission State Aid Notice, supra note 106, at 31.
} 
If the advantage is supplied by the state acting as a shareholder for a specific firm, the question comes down to "whether the undertaking could have obtained the amounts in question on the capital market." 110 As for cases where the aid to a firm is supplied through "logistical and commercial assistance by a public undertaking to its subsidiaries," the criterion is whether the remuneration obtained for such assistance is in line with "normal market conditions." ${ }^{111}$ Here, because certain firms are by hypothesis targeted, the advantage that would be obtained under normal market conditions is the focus, and not selectivity. The Commission makes clear that normal market conditions means "in the absence of state intervention." 112 The Commission has sometimes insisted that it must be established that the impugned measure remedies market failures and that these failures could not be remedied more "directly," "113 but this requirement is not widespread in state aid case law and commentary. All this being said, what needs to be pursued by the state furnishing money or services is not "short-term" but "long-term" profitability, and even then, profitability must merely not be "disregarded" completely. ${ }^{114}$

Once a measure is considered illegal state aid under article 107(1) TFEU, there are several exemptions that can nevertheless apply. Articles 107(2) and 107(3) TFEU provide several such exemptions, including "aid to promote the economic development of areas where the standard of living is abnormally low or where there is serious underemployment," "aid to facilitate the development of certain economic activities or of certain economic areas, where such aid does not adversely affect trading conditions to an extent contrary to the common interest," and aid "to remedy a serious disturbance in the economy of a Member State." Additionally, article 106(2) TFEU has been interpreted as exempting firms that have "public service" obligations and/or perform services of "general interest." ${ }^{115}$ More generally, state activities that are "political" as opposed to "economic" are excluded from state aid rules. ${ }^{116}$ This includes the provision of infrastructure to firms if it can be argued to be part of "activities the State normally performs in the exercise of its public powers." 117

I am less interested in the exceptions than in the inquiry into what state measures "distort" instead of mimicking or supporting the market in the first place. The exceptions turn on the interpretation of concepts like "political" or "common interest" and do not involve the fundamental question of what institutions constitute the market to start with. In fact, the exceptions presuppose an answer to that prior question, because they apply only to distortions of the market (in other words to a measure found to be illegal state aid). To come back to my initial question, then, a Member State wishing to render its industries less vulnerable to loss of competitiveness caused by an ambitious green agenda would have to argue that the measures taken for this purpose either are not "selective" or do not confer an "advantage" over and above what a "normal" market would provide, if not in the short term then at least in the long term.

As for the other question I raised-whether instead of generally seeking to increase competitiveness, a Member State could provide aid to its industries to compensate for the costs of environmental regulations - the answer is that it depends. If the "regulatory burden" that is sought to be compensated for is "of a different nature" than and "unconnected" to the compensating measure, there will be an advantage and potentially illegal state aid. ${ }^{118}$ It is said that measures will be connected "if they form part of the same tax system," or if they constitute "a direct or indirect form

\footnotetext{
${ }^{110}$ Case C-142/87, Belgium v. Commission, 1990 E.C.R. I-959, para. 26.

${ }^{111}$ SFEI, Case C-39/94, at paras. 60-61.

${ }^{112}$ Commission State Aid Notice, supra note 106, at 15.

${ }^{113}$ See the references cited in Phedon Nicolaides, The Economics of Granting and Controlling State Aid, in EC STATE AIDS 17, 31 (Leigh Hancher, Tom Ottervanger \& Piet Jan Slot eds., 3d ed. 2006).

${ }^{114}$ BACON, supra note 102, at 40; CRAIG \& DE BURCA, supra note 99, at 1135.

${ }^{115}$ CRAIG \& DE BurCA, supra note 99 , at 1122 .

${ }^{116}$ BACON, supra note 102 , at 23.

${ }^{117}$ Commission State Aid Notice, supra note 106, at 44.

${ }^{118} \mathrm{Id}$. at 16 .
} 
of compensation for each other." ${ }^{119}$ Such terms will need to be interpreted and applied in the usual course of adjudication, and it is very hard to know in advance what kind of measure will be considered "connected," or "regulatory" for that matter. ${ }^{120}$ But it seems likely that it will be considered illegal for a measure to directly compensate for new environmental obligations under the Green Deal. This is strongly suggested by the fact that the block exemptions adopted by the Commission to render legal certain subsidies limit the exemption of environmental subsidies to those favoring producers that "increase the level of environmental protection ... by going beyond the applicable Union standards." 121 The existence of EU environmental standards, that is, seems to prevent a Member State from compensating its producers for abiding by such standards.

\section{A Legal Institutionalist Critique of Subsidy Law: Daniel Tarullo's "Beyond Normalcy"}

The legal institutionalist trade analysis I propose to appropriate was established by Daniel Tarullo in his landmark article Beyond Normalcy in the Regulation of International Trade. ${ }^{122}$ Tarullo's article was a critique of the aggressive use by the United States in the 1970s and onwards of trade laws authorizing unilateral imposition of tariffs to "countervail" policies amounting to "dumping" or "subsidies" - the American and international equivalent of state aid. Tarullo's analysis seems to have been motivated by a will to limit American policies penalizing developing-country imports coupled with concern for mounting inequality within the U.S. This is basically the spirit that animates my own approach here, and I propose to adopt Tarullo's analysis, albeit emphasizing certain aspects of it over others.

In fact, the situation addressed by Tarullo whereby a more-developed country blocks attempts by less-developed countries to build new competitive advantages might well materialize in the European context, if certain Member States were to implement the strategy I propose of supporting their industries so as to compensate the effects of Green Deal regulations. Eventual findings by the European Commission that such support is illegal state aid would be analogous to the American countervailing duties that were criticized by Tarullo. Moreover, the general conceptual apparatus used then and now by American trade authorities to conclude that a subsidy is illegal is identical to EU state aid criteria insofar as it requires a "financial contribution" conferring a "benefit" that detracts from normal market conditions and that is "specific."123

Tarullo's central argument was that the legal definition of "subsidies" is ambiguous and depends on what we posit to be the "normal" market baseline, from which any given governmental program can be seen to be a deviation. Tarullo showed that there are several such baselines that can be posited and that which baseline we choose will change the outcome of the countervailing duty proceedings - that is, justifying or not justifying American tariffs in any given instance. In other words, the argument was that the entire analysis used by American authorities to justify penalizing developing-country firms was shaky, and that this should induce restraint on the part of the U.S.

The first step in Tarullo's argument was that we cannot simply equate all government interventions giving an advantage to certain industries with illegal subsidies, because market failures render government intervention desirable. Tarullo cited Arthur C. Pigou and the concept of

\footnotetext{
${ }^{119}$ Erika Szyszczak, Criterion of Advantage, in State Aid Law Of The European Union 84, 85 (Herwig Hofmann \& Claire Micheau eds., 2016).

${ }^{120}$ See Commission State Aid Notice, supra note 106, at 100.

${ }^{121}$ Commission Regulation (EU) No 651/2014 of 17 June 2014, Declaring Certain Categories of Aid Compatible With the Internal Market in Application of Articles 107 and 108 of the Treaty, art. 36(2)(a), 2014 O.J. (L 187 ) 1.

${ }^{122}$ Daniel K. Tarullo, Beyond Normalcy in the Regulation of International Trade, 100 HaRV. L. REV. 546 (1987).

${ }^{123}$ See Ralph F. Folsom, Principles Of International Trade Law, Including The World Trade Organization, Technology Transfers And Import/Export/Customs LAW 200 (2d ed. 2018).
} 
"externality," ${ }^{24}$ stating the conventional idea that a positive externality might require a government subsidy for efficiency to obtain. ${ }^{125}$ Tarullo's examples included R\&D and employee training, two cases of positive externalities that arguably render subsidies legitimate. We might add all manner of public goods like infrastructure, health, education, a legal system, etc. Given market failures and the need for some government intervention, efficiency, not laissez-faire, should be the guiding principle of subsidy law.

Tarullo argued that it is often very hard to tell apart efficient from inefficient government interventions across an entire economy, because " $t \mathrm{t}]$ he cumulative effects of government intervention are so complicated that one cannot disentangle these effects from some hypothetical underlying, undistorted market." 26 Tarullo gave the examples of environmental and securities regulation, which raise costs, and of government provision of public goods like communication and transportation infrastructure, which lowers costs. Both are routinely seen as efficient, yet their co-existence makes the assessment of the distortive impact of any single government intervention hopelessly complex. Tarullo added that the "specificity" test used in American subsidy law, and identical to the EU state aid "selectivity" criterion, was inconclusive. He argued that "specificity" is weakly correlated with efficiency, because we can easily imagine specific financial grants that remedy market failures and general grants that do not. ${ }^{127}$

There were more radical steps in Tarullo's argument that did not reduce to the claim that there are too many government interventions through tax and transfer for us to be able to confidently identify those that, on net, distort the market and amount to illegal subsidies. Here is Tarullo discussing what he calls a "true cost" analysis-which is an analysis of the actual efficiency of a government measure irrespective of whether it is "specific:"

There is a more fundamental problem with true cost analysis, that of translating its theoretical assumptions into practice. A true cost analysis assumes that one can separate laws establishing basic private property rights and a basic market system from those effecting government interventions. The former are prerequisites for a market system while the latter are assumed sufficiently discrete to be subject to a cost-benefit analysis. Useful as this assumption may be in theory, it necessarily breaks down in concrete situations. First, although property rights are defined and enforced through government intervention, many government programs are intended both to shift property rights and to serve other functions such as regulation. Second, a market system is also created by the state through devices such as the law of contract. The laws that transform the idea of a market into an actual institution are accompanied by ambiguity, necessary arbitrariness, and significant transaction costs. Basic choices about the kind of contract system to be adopted affect the costs of the activities under analysis. As a practical matter, then, there is no coherent concept of "cost" that is not associated with choices about the form of state intervention that will create property and contract rights. ${ }^{128}$

The reference cited to support these statements was an article by Duncan Kennedy and Frank Michelman, ${ }^{129}$ a seminal piece expounding the legal institutionalist view of "bundles of rights"130 as leading to multiple different efficient outcomes. In this approach initially advanced by the likes

\footnotetext{
${ }^{124}$ See Arthur Pigou, The Economics of Welfare 192-96 (4th ed. 1932). For a systematic theorization of market failures as involving different kinds of externalities, see Francis Bator, The Anatomy of Market Failure, 72 Q.J. ECON. 351, 363 (1958).

${ }^{125}$ See Tarullo, supra note 122 , at 557.

${ }^{126} I d$. at 558.

${ }^{127} \mathrm{Id}$. at 560 .

${ }^{128} I$ d. at $558-59$, footnotes omitted.

${ }^{129}$ Duncan Kennedy \& Frank Michelman, Are Property and Contract Efficient?, 8 Hofstra L. ReV. 711 (1980).

${ }^{130}$ See Jane B. Baron, Rescuing the Bundle-of-Rights Metaphor in Property Law, 82 U. CIN. L. Rev. 57, 61-79 (2013).
} 
of Oliver Wendell Holmes and the American legal realists, ${ }^{131}$ property rights and freedom of contract are not legal institutions with a single definition or scope, but groupings of more specific vulnerabilities and privileges that can be arranged in many different ways. ${ }^{132}$

According to the bundle of rights view, legal injury to some freedom/right is the corollary of any other existing freedom/right. To exercise one's freedom of action is very often, if not always, to impinge on the other's freedom from harm, or on their rights to security. Employment law rules, as well as property law rules on what rights of access non-owners have and tort law rules on what nuisances and damages individuals can inflict one another, can be configured in many different ways all faithful to the idea of equal rights and freedoms. There are therefore many possible distributions of the "coercive" economic power that these legal rules confer. ${ }^{133}$ Tarullo quite explicitly drew on this tradition in making his argument that private law rules change the cost structures of traded-good industries.

This led Tarullo to conclude that, because the undistorted market at the heart of subsidy law can take many forms depending on what private laws shape it, judgments about which government interventions are "efficient" are irremediably bound up with political decisions about distribution. ${ }^{134}$ This led him to argue for a rolling back of American unilateral countervailing duties, in the name of the need for the U.S. to respect "the sovereign actions of a government making basic policy decisions." 135 Tarullo also proposed decoupling American policies to help struggling workers and industries from trade considerations, and putting in place more ambitious industrial policies to move displaced workers into new, more democratically-managed industries. ${ }^{136}$

\section{The Consequences of Legal Institutionalism for Trade Theory}

Tarullo's insight has broader consequences than merely leading one to oppose excessive or unilateral countervailing of subsidies. Instead, thinking rigorously about competitive advantage as being legally constructed leads to a quite thorough rethinking of traditional legal and economic theories of free trade. The first step in developing this analysis is, as already mentioned, to distinguish between the claim that the real world is too complex for us to be able to identify which measures are on net distortive or efficient and the deeper legal institutionalist point that even a perfectly competitive and market-failure-free market can take many different forms, depending on how legal rules shape it. Kerry Rittich provides a useful articulation of the legal institutionalist point, explicitly drawing on Tarullo's article and distinguishing the argument about the omnipresence of tax-and-transfer programs from the deeper one about the role of "legal entitlements" in subsidizing different economic activities:

The reason for such [trade law] disputes is that subsidies extend well beyond the practice of channelling funds to particular companies or industries through industrial policy and the selective allocation of credit. In almost all economies, subsidies to production are arguably present in everything from state provision of physical and institutional infrastructure and regional transfer payments to contributions to the health and education of workers. But contestation over subsidies also flows from the fact that, as is transparently obvious to entrepreneurs engaged in globalized production, the costs of production are a function of the legal environment. Thus, subsidies may be provided by the presence or absence of legal

\footnotetext{
${ }^{131}$ See Joseph Singer, The Legal Rights Debate in Analytical Jurisprudence from Bentham to Hohfeld, (1982) WIS. L. REV. 975, 1034-49.

${ }^{132}$ See Wesley N. Hohfeld, Some Fundamental Legal Conceptions as Applied to Judicial Reasoning, 23 YALE L.J. 16, 36-37 (1913); Walter W. Cook, Privileges of Labor Unions in the Struggle for Life, 27 YALE L.J. 779, 788 (1918).

${ }^{133}$ Robert Hale, Coercion and Distribution in a Supposedly Non-Coercive State, 38 POL. SCI. Q. 470, 474-75 (1923).

${ }^{134}$ Tarullo, supra note 122 , at $577-78$.

${ }^{135} \mathrm{Id}$. at 578 .

${ }^{136} \mathrm{Id}$. at 621 .
} 
entitlements. In neoliberal market reform discourse, some of these very production subsidies form part of the framework for economic growth and development without being identified as such. For example, the absence of robust labor and employment or environmental regulation provides subsidies to enterprises vis-à-vis competitors in jurisdictions where they are present. Extended intellectual property protection which states are now required to provide creates a massive subsidy or transfer of wealth to rights holders such as pharmaceuticals. ${ }^{137}$

The second step in fully exploring the consequences that flow from this legal institutionalist theory would be to elaborate, following Rittich's lead, a taxonomy of all the legal rules and institutions that can distribute competitive advantage differently even under perfectly competitive markets for traded goods. The rules of private law mentioned by Tarullo are an important example at a conceptual level, although in the real world subsidization through private law probably played a small role in countries that have consciously directed competitiveness gains towards certain industries. ${ }^{138}$ Corporate and antitrust rules on what firm collaboration and mergers are permissible to attain economies of scale were more important levers for recent transfers of competitive advantage towards the developing world, such as in Japan, the East Asian Tigers, and China. ${ }^{139}$ That said, the most important levers used in recent decades were probably monetary: subsidies given through central bank monetary policy, fiscal tax and transfer, and domestic development banks, ${ }^{140}$ as well as through "currency manipulation"-which can be done by buying foreign currency to keep domestic currency, and therefore domestic traded goods, relatively cheap. ${ }^{141}$

I leave full exploration of the precise ways in which these different rules subsidize production for future work and limit myself to the following general remarks. In tracing the ways in which each of these sets of rules and institutions create competitive advantage, one faces different established theorems according to which the rules in question are "neutral" in that they do not affect the market allocation of resources at least in the long run. For example, in the context of private law rules, we have the Coase Theorem according to which the allocation of resources is not affected by a change in who is favored by contract and tort law if transaction costs are low enough. ${ }^{142}$ In the case of central-bank monetary stimulus and competitive devaluations, the argument is that any stimulation in output or increase in the competitiveness of domestic goods vis-à-vis foreign ones will be canceled out in the long run as domestic prices uniformly rise to offset the impact of the policy. ${ }^{143}$

In countering these "neutrality" arguments, we can draw on many existing analyses. For instance, it has been shown that the Coase Theorem often fails to hold because of pervasive "wealth effects" caused by the shifting of contract, tort, and property rules. ${ }^{144}$ On the monetary side, we can draw on analyses that show that monetary policy-referring broadly to central-bank, fiscal,

\footnotetext{
${ }^{137}$ Kerry Rittich, Recharacterizing Restructuring: Law, Distribution and Gender in Market Reform 162-63 (2002).

${ }^{138}$ The debates on the role of limited tort liability for the nuisances inflicted by railroad companies during the AngloAmerican industrial revolution seem to be a counter-example where private law was important in favoring certain industries. See Anna di Robilant, Abuse of Rights: The Continental Drug and the Common Law, 61 Hastings L.J. 687, 724-29 (2010).

${ }^{139}$ For a comparative description of these development models, see Seung-Wook Baek, Does China Follow "The East Asian Development Model”?, 35 J. ConTemp. Asia 485, 498 (2005).

${ }^{140}$ See Mark Wu, The "China, Inc." Challenge to Global Trade Governance, 57 HARV. INT'L L.J. 261, 301 (2016).

${ }^{141}$ See Bryan Mercurio \& Celine Sze Ning Leung, Is China A “Currency Manipulator"?: The Legitimacy of China's Exchange Regime Under the Current International Framework, 43 INT'L LAW. 1257, 1270-83 (2009).

${ }^{142}$ See Ronald H. Coase, The Problem of Social Cost, 3 J.L. \& ECON. 1, 15 (1960).

${ }^{143}$ On monetary policy see Andrew Abel, Ben S. Bernanke \& Dean Croushore, Macroeconomics 493-504 (6th ed. 2008). On the inflationary impact and long-run allocative neutrality of competitive devaluations, see KRUGMAN \& OBSTFELD, supra note 89 , at $472-74$.

${ }^{144}$ See Mario J. Rizzo, Thee Mirage of Efficiency, 8 Hofstra L. Rev. 641, 648 (1980); Duncan Kennedy, Cost-Benefit Analysis of Entitlement Problems: A Critique, 33 Stan. L. Rev. 387, 427-28 (1981).
} 
and exchange-rate policy—can increase not only prices but also output even in the long run. ${ }^{145}$ To be sure, there will always be costs correlative to the benefits vested by a private law rule or a fiscal/ monetary intervention. To take just two examples: exempting a machinery exporter from liability for damage to properties neighboring the factory hurts the owners of these properties, and depreciating a currency to make exports and import-competing goods cheaper hurts importers. Developing the theory will require a thorough mapping of these costs and benefits, and "constructing" competitive advantage in this sense always involves sacrificing other domestic actors to privilege traded-good producers. Fleshing out in this way the idea that competitive advantage is constructed might lead us to the following generalization offered by David Kennedy:

[W]hat economists call "competitiveness" and "substitutability" depend in part on the legal and institutional arrangements that affect things like costs of production and barriers to entry in the two industries, the structure of these (and other) industries in both countries, the relative power of labor and capital invested in the two industries, the monopoly power of producers in each industry, the distribution of preferences and the process by which preferences are shaped in the two countries, and so on .... Changing arrangements that have this kind of market-shaping effect could change a country's bargaining power, the competitiveness of its products, or the productivity of its factors and thereby affect the distribution of gains [from trade]. ${ }^{146}$

If countries can always construct more competitive industries by changing the legal rules that shape production, trade is to a significant extent zero-sum, an idea that is rejected by many free trade theorists as entailing a wrong-headed "mercantilist" prioritization of exports over imports. ${ }^{147}$ In fact, the implication of the legal institutionalist theory laid out here is not the mercantilist one that exports are good and imports are bad. Instead, it is that the competitiveness of exports and import-competing goods can be distributed in many different ways depending on which policies countries adopt to shift economic advantage towards their traded-good industries. Whether a country is better off importing a product or producing it itself, and whether a trade deficit is to be avoided, depends on many institutional details like those described in Section B(III) above. But we can certainly not say in the abstract that "free trade" is better than trade "distortions," because there are many different free trade regimes that reconfigure the magnitude and the distribution of the gains from trade.

In traditional trade theory, competitiveness is a function mostly of technology, as in the Ricardian model, and of factor endowments, as in the Heckscher-Ohlin model. ${ }^{148}$ My approach here is not to deny the role of these elements but to add the factor of legal rules subsidizing tradedgood producers. This element would be largely determinative among countries with similar technologies and factor endowments. Moreover, legal subsidies can overcome insufficient technological productivity or lesser factor endowments that would otherwise make a specific good uncompetitive. The approach I propose, then, is to acknowledge that other things besides legal subsidies determine which country can trade what good at what cost, but also to point out that many of these other things can be acquired by different countries if they can overcome existing competitive disadvantages and develop productive capacity. The instruments used to surmount

\footnotetext{
${ }^{145}$ For some starting points for the development of such an economic theory, see Paul Davidson, Keynes's Finance Motive, 17 Oxford Econ. Papers 47, 58 (1965); L. Randall Wray, Understanding Modern Money: The Key to Full Employment and Price Stability 77-78 (1998); Christine Desan, Making Money: Coin, Currency, and the COMING OF CAPITALISM 432-33 (2014).

${ }^{146}$ David Kennedy, A World of Struggle: How Power, Law, and Expertise Shape Global Political Economy 178-79 (2016).

${ }^{147}$ Robert E. Hudec, Developing Countries in the GATT Legal System 126 (2001).

${ }^{148}$ See KRUGMAN \& OBSTFELD, supra note 89, at 31 (describing both models).
} 
the disadvantages, as in new trade theory and heterodox development economics, are production subsidies, as well as infant industry tariffs. ${ }^{149}$

\section{Implications for Environmental Policy}

\section{Drawing on International Environmental Legal Theory}

This bit of trade theory leads to the conclusion that the distributive impact of environmental measures, and specifically the impact of these measures on the relative competitiveness and vulnerability to macroeconomic destabilization of various states and regions, should be at the heart of discussions. In developing this insight, there is much international environmental legal theory we can draw on emphasizing the asymmetric capabilities and responsibilities of different states and regions of the globe. In these strands of environmental legal theory, environmental justice is inseparable from distributive justice. This is by contrast to the view cited above of environmental policy as a "normative program for the world community." 150

Critiques of international environmental protection measures as reinforcing geopolitical injustices are longstanding, ${ }^{151}$ and differentiated responsibilities whereby richer and more powerful countries shoulder more of the costs of environmental protection have long figured in international negotiations of environmental treaties-with strong resistance by some richer and more powerful countries. ${ }^{152}$ Famously, the Kyoto Protocol ${ }^{153}$ concluded under the United Nations Framework Convention on Climate Change ${ }^{154}$ exempted less-developed countries from its greenhouse gas reduction obligations. ${ }^{155}$ The 2015 Paris Agreement, ${ }^{156}$ the successor to the Kyoto Protocol, while it did not exempt less-developed countries completely, left considerable leeway for states to define their "nationally-determined," "highest possible" contribution to reaching the collective goal of limiting global warming to two degrees Celsius above pre-industrial levels. ${ }^{157}$ The Paris Agreement explicitly recognizes that reaching the agreement's goals "will take longer for developing country Parties"158 and that "Developed country Parties should continue taking the lead by undertaking economy-wide absolute emission reduction targets."159

The Paris Agreement binds "Developed country Parties [to] provide financial resources to assist developing country Parties." 160 It also creates a "Technology Mechanism" to implement a "long-term vision on the importance of fully realizing technology development and transfer

\footnotetext{
${ }^{149} \mathrm{On}$ infant industry tariffs and subsidies see ThOMAs Pugel, InTERNATIONAL ECONOMics 209-12 (14th ed. 2009). In this literature, the most common factor identified as underpinning the acquisition of competitive advantage behind the shield of infant industry tariffs or subsidies is economies of scale or increasing returns to scale caused by positive externalities from R\&D and knowledge - sometimes leading theorists to posit a "ladder of comparative advantage" and "dynamic gains" from exports that allow countries to climb to more productivity-requiring goods. See Paul Krugman, Is Free Trade Passé?, 1 J. EcON. Persp. 131, 137-38 (1987); Gerald M. Meier, Biography of a Subject: An Evolution of Development Economics 107 (2005).

${ }^{150}$ Dupuy, supra note 8 , at 422 .

${ }^{151}$ For an early example, see generally Anil Agarwal \& Sunita Narain, Global Warming in an Unequal World: A Case of Environmental Colonialism, 1991 EARTH IsLAND J. 39 (1991).

${ }^{152}$ For an account of this resistance, see Paul G. Harris, Common but Differentiated Responsibility: The Kyoto Protocol and United States Policy, 7 N.Y.U. ENVTL. L.J. 27, 42 (1999).

${ }^{153}$ Kyoto Protocol to the United Nations Framework Convention on Climate Change, Dec. 10, 1997, 2303 U.N.T.S. 162 [hereinafter Kyoto Protocol].

${ }^{154}$ United Nations Framework Convention on Climate Change, May 9, 1992, S. Treaty Doc No. 102-38, 1771 U.N.T.S. 107 [hereinafter UNFCCC].

${ }^{155}$ See Lee, supra note 36 , at $135-36$.

${ }^{156}$ Paris Agreement to the United Nations Framework Convention on Climate Change, Dec. 12, 2015, T.I.A.S. No. 16-1104 [hereinafter Paris Agreement].

${ }^{157} I d$. art. 4(3).

${ }^{158} I d$. art. 4(1).

${ }^{159} I d$. art. 4(4).

${ }^{160} \mathrm{Id}$. art. 9.
} 
in order to improve resilience to climate change and to reduce greenhouse gas emissions." 161 The Kyoto Protocol had also led to the creation of a "framework" for technology transfer. ${ }^{162}$ Such transfer is of course a well-established demand in the field of economic development and debates on the international distribution of economic welfare more broadly. ${ }^{163}$ Yet, it has been noted that so far international mechanisms for environmentally-oriented technology transfer have amounted to precious little. ${ }^{164}$

Nevertheless, foregrounding the issue of technological transfer usefully points to deeper determinants of national income and environmental capacity than does the mere obligation to transfer funds. This move also lends itself quite well to the kind of trade-oriented distributive analysis I provided above, although environmental legal theory dealing with technology transfer sometimes does not engage with more fine-grained issues of trade competitiveness (and the interests of the workers involved). ${ }^{165}$ Similarly, if the Kyoto Protocol and Paris Agreement negotiations have featured much discussion of inequalities and distributive concerns in general and of the transfer of funds and technology in particular, trade competitiveness and its impact on the macroeconomic policies of states seem to have been largely absent from the discussions. One of the consequences of neglecting the deeper trade ramifications of inequalities in competitiveness and income is that one risks missing the fact that, often but by no means always, "technology" can be homegrown in the form of physical-capital accumulation and organizational know-how development-provided the required subsidies and coordination can be mobilized. ${ }^{166} \mathrm{I}$ am speaking here not only of green technologies per se but also more generally of competitiveness-enhancing productivity increases that can allow firms to meet more stringent and costly environmental standards. ${ }^{167}$

On a more rhetorical or discursive level, the Paris Agreement explicitly incorporates distributive issues in its description and framing of climate change issues. For example, its preamble mentions the need to protect "human rights, the right to health, the rights of indigenous peoples, local communities, migrants, children, persons with disabilities and people in vulnerable situations and the right to development, as well as gender equality, empowerment of women and intergenerational equity" in acting against climate change. ${ }^{168}$ The agreement also states that measures to adapt to the impacts of climate change should take a "country-driven, gender-responsive, participatory

\footnotetext{
${ }^{161} I d$. art. 10.

${ }^{162}$ Kyoto Protocol, supra note 153, art. 11(2)(b); UNFCCC, supra note 154, art. 4(1)(c), 4(3), 4(5), 4(9). On the evolution of technology transfer mechanisms under the Kyoto Protocol, see Liliana B. Andonova, Paula Castro \& Kathryn Chelminski, Transferring Technologies: The Polycentric Governance of Clean Energy Technology, in Governing Climate Change: PolyCENTRICITY IN ACTiOn? 266, 268 (Andrew Jordan et al eds., 2018).

${ }^{163}$ See, e.g., G.A. Res. 3201 (S-VI), art. 4(p), Declaration on the Establishment of a New International Economic Order (May 1, 1974); G.A. Res. 39/163, art. 13(2), Charter of Economic Rights and Duties of States (Dec. 17, 1984).

${ }^{164}$ See Obiora Chinedu Okafor (Independent Expert on Human Rights and International Solidarity), International Solidarity and Climate Change, at 15, A/HRC/44/44 (Apr. 1, 2020).

${ }^{165}$ See, e.g., Dalindyebo Shabalala, Climate Change, Human Rights, and Technology Transfer, in New TECHNOLOGIES FOR Human Rights Law And Practice 46, 53-55 (Molly K. Land \& Jay D. Aronson eds., 2018); Okafor, supra note 164. For an example of scholarship on environmental technology transfer that does engage with trade and industrial policies, see David Popp, International Technology Transfer, Climate Change, and the Clean Development Mechanism, 5 ReV. ENVTL. ECON. \& POL'Y 131, 137-39 (2011).

${ }^{166}$ I would say that the other frequently-invoked strategy of imposing corporate-law-based environmental duties on richercountry multinationals, useful though such an imposition of liability would be, also does not look deeply enough at the trade and organizational determinants of international inequality. This defect prevents us from thinking through ways in which competitiveness and welfare could be durably transferred from North to South by giving the South some powerful firms of its own, too. For an example of the strategy of imposing corporate law duties on Northern multinationals, see Lisa Benjamin, The Responsibilities of Carbon Major Companies: Are They (And Is the Law) Doing Enough?, 5 Transnat'L ENVTL. L. 353, 357 (2016).

${ }^{167}$ The phenomenon I have in mind overlaps with the acquisition of competitive advantage described in the "infant industry" literature. See Pugell, supra note 149.

${ }^{168}$ Paris Agreement, supra note 156, preamble.
} 
and fully transparent approach, taking into consideration vulnerable groups, communities and ecosystems."169

Within international environmental law scholarship, such distributive concerns have been grounded in various legal and political concepts. Some theories draw on the right to a decent minimum standard of living, ${ }^{170}$ while others invoke the right to development. ${ }^{171}$ Others still draw on "solidarity" understood as an international legal principle. ${ }^{172}$ Some yet more radical strands of environmental theory like the literature on "ecological debt" emphasize the distributive aspects of environmental policy by "trac[ing] many of the benefits presently enjoyed by the North to its longstanding ability to draw upon global resources." ${ }^{173}$ Colonialism or quasi-colonialism is often identified as the source of the North's ability to command access to global resources. ${ }^{174}$ The policy implications of these theories are not always very specific, beyond general international redistribution and shifting the burden to reduce pollution towards the Global North and away from the Global South. ${ }^{175}$ As already mentioned, a quite useful strand of the more radical environmental legal literature articulates these distributive justice issues not only between nations or regions but also within regions, along axes of social class for instance. ${ }^{176}$ This is the kind of perspective I try to develop in this Article, honing in more directly on traded-good sectors and the impact of asymmetric competitiveness on workers.

Based on the foregoing it would appear that my proposed introduction of distributive considerations in environmental legal theory is largely already done. Yet an analysis framed in terms of unequal development and historical "appropriation" of resources is hard to transpose to the EU, and to other cases not involving colonial or quasi-colonial domination. The right to development and the right to an adequate standard of living are also unlikely to carry much weight in the EUwhere countries are more economically homogeneous than at the international level. I see it as one point of added value of my approach that it allows for the consideration of unequal trade patterns in environmental law even in the absence of past colonial relationships, in a regional European context in which countries are less heterogeneous.

Indeed, in my approach, it is not only colonialism or even power that creates economic inequalities, but often the mere fact of having gotten away with an initial subsidization scheme that perhaps led to fist-mover advantages and spurred technological improvement and capital accumulation. ${ }^{177}$ My view of competitive advantage as legally constructed is therefore amenable to a normative project of redistributing competitive advantage towards poorer and lesscompetitive nations even in the absence of North-South colonial or quasi-colonial injustices to remedy. This normative project requires a theory of desert and justice across borders, and I would favor a generally very egalitarian policy based on the idea that the "birthright lottery" should not determine one's wealth and place in the world distribution of income. ${ }^{178}$

\footnotetext{
${ }^{169} I d$. art. 7(5).

${ }^{170}$ See Sivian Kartha, Simon Caney, Navroz K. Dubash \& Greg Muttitt, Whose Carbon Is Burnable? Equity Considerations in the Allocation of a 'Right to Extract', 150 Climatic Change 117, 123 (2018).

${ }^{171}$ See generally Lars Löfquist, Climate Change, Justice and the Right to Development, 7 J. GLOв. ETHICs 251 (2011).

${ }^{172}$ Okafor, supra note 164 , at 4.

${ }^{173}$ Karin Mickelson, Leading Towards a Level Playing Field, Repaying Ecological Debt, or Making Environmental Space: Three Stories About International Environmental Cooperation, 43 OsGoode Hall L.J. 137, 154 (2005).

${ }^{174}$ See, e.g., Lavanya Rajamani, Differential Treatment in InTernational EnVironmental Law 3-5 (2006).

${ }^{175}$ See id. at 157. See, to a similar effect, Mario Prost \& Alejandra Torres Camprubi, Against Fairness? International Environmental Law, Disciplinary Bias and Pareto Justice, 25 LEIDEN J. INT'L L. 379, 387 (2012) (describing the literature based on "sustainable development").

${ }^{176}$ See Khoday \& Natarajan, supra note 10.

${ }^{177}$ For a roughly similar approach, see Alice Amsden, The Rise of the Rest: Challenges to the West FROM LATEINDUSTRIALIZING ECONOMIES 57-59 (2001).

${ }^{178}$ See Ayelet Schachar, The Birthright Lottery: Citizenship and Global Inequality 21-23 (2009).
} 
I have outlined in detail my favored egalitarian political philosophy elsewhere with a more domestic focus. ${ }^{179}$ It does not seem necessary to fully make the case for such an approach here because the drastic differences in national income one finds even within the relatively homogeneous European Union strike me as very hard to justify on grounds of "merit" or as otherwise just. The wealth of nations, perhaps even more so than the wealth of individuals, is plainly the result of the contingencies of history and sheer luck, as well as the trade subsidization and firstmover advantages just mentioned. I doubt anyone would seriously maintain that it is just for someone born in Germany or the Netherlands to have access to such a vastly greater per capita national income than someone born in Bulgaria or Greece. I note that regardless of whether one is in favor of much or just a little redistribution between states, the analysis presented here remains relevant. As long as the status quo is considered unjust, its maintenance or worsening by an ambitious green agenda with no accompanying redistribution should be of concern. Because it seems likely that many readers will find the status quo distribution of income between European nations at least a little unjust, I feel justified in not burdening this Article with a lengthy discussion of distributive justice across borders.

One might of course find other objections to redistribution towards poorer states than that of holding the present inequalities justified, for instance based on the anticipation that defective governance structures will squander the redistributed income or power. These concerns, however well-founded, are not in my view convincing general objections to redistribution. This is because I do not think it fair to hold populations responsible for the failures of their governments and elites. These moral and political considerations, which I have mostly kept outside the scope of this Article and which have been analyzed in detail in the existing literature already, ${ }^{180}$ underpin my belief that competitive advantage should be redistributed from countries like Germany and the Netherlands to countries like Greece and Bulgaria.

Finally, one might question whether enabling more competitive production in Greek and Bulgarian export and import-competing industries will necessarily raise the national incomes of these countries. One might also wonder whether job losses in German and Dutch traded-good sectors might simply be replaced by non-tradable-sector jobs that generate the same contribution to national income. If competitiveness had such little bearing on national income, it would not be a good proxy for economic well-being or indeed a relevant consideration for questions of international distribution and justice. But given the role of trade competitiveness in stabilizing capital flows and the cost of public debt under a fixed exchange rate or common currency, ${ }^{181}$ and assuming lower-income Member States target industries with a higher potential to contribute to growth, ${ }^{182}$ gaining (losing) competitive advantage is in fact likely to lead to higher (lower) national income. It is thus likely to be a useful lever of egalitarian redistribution across borders.

\section{Rethinking EU Environmental Policy}

EU environmental policy already incorporates questions of interstate distributive justice to a nonnegligible extent. For instance, TFEU article 191, which imposes on EU institutions an obligation to attain a "high level of [environmental] protection," subjects that obligation to consideration of "environmental conditions in the various regions of the Union" and "the economic and social development of the Union as a whole and the balanced development of its regions." ${ }^{183}$

\footnotetext{
${ }^{179}$ See McDougall, supra note 14 , at 192-201.

${ }^{180}$ See, e.g., Odette Lienau, Rethinking Sovereign Debt: Politics, Reputation, and Legitimacy in Modern Finance 5-6 (2014).

${ }^{181}$ See supra section $\mathrm{B}(\mathrm{III})$.

${ }^{182}$ These are likely to be industries producing goods situated higher in the "ladder of comparative advantage" mentioned previously. See Krugman, supra note 149.

${ }^{183}$ Van Calster and Reins report that this clause is often invoked in EU policy discussions. See GEERT VAN CALSTER \& LEONIE ReIns, EU ENVIRONMENTAL LAW 11 (2017).
} 
The EU's "effort-sharing decisions" to distribute uneven commitments based on GDP per capita towards meeting the EU's collective target under the Kyoto Protocol and Paris Agreement represent another example of distributive considerations being integrated in European environmental law. ${ }^{184}$ Within the ETS, an effort is also made to award more allowances to low-income EU Member States than these countries would obtain under the applicable formula which looks at the level of emissions of each country when the ETS was introduced in $2005{ }^{185}$

The Green Deal itself, perhaps in part because the Commission anticipated that its suggested strengthening of environmental regulations and taxes would cause concern in poorer and lesscompetitive states, proposes to relax state aid rules to enable greener production processes. ${ }^{186}$ The Green Deal indeed states that the Commission will "support other initiatives leading to alliances and to a large-scale pooling of resources, for example in the form of Important Projects of Common European Interest, where targeted time-bound State aid can help build new innovative value chains." 187 Moreover, the Green Deal proposes a "Just Transition Mechanism" and a "Just Transition Fund," for which it provides the following rationale:

The transition can only succeed if it is conducted in a fair and inclusive way. The most vulnerable are the most exposed to the harmful effects of climate change and environmental degradation. At the same time, managing the transition will lead to significant structural changes in business models, skill requirements and relative prices. Citizens, depending on their social and geographic circumstances, will be affected in different ways. Not all Member States, regions and cities start the transition from the same point or have the same capacity to respond. These challenges require a strong policy response at all levels. ${ }^{188}$

The very next sentence indicates that the Just Transition Mechanism will "focus on the regions and sectors that are most affected by the transition because they depend on fossil fuels or carbonintensive processes." 189 For those sectors, the Green Deal will "strive to protect the citizens and workers most vulnerable to the transition, providing access to re-skilling programmes, jobs in new economic sectors, or energy-efficient housing." 190

What is notable about these passages on the Just Transition Mechanism is that, in the end, the focus is on regions that pollute more, and not on generally lower-income or less-competitive regions. Although in exceptional cases the more polluting regions are also the poorer ones, in general, the opposite is true. ${ }^{191}$ And in any event, alleviating the burden of regulations and taxes on the more polluting sectors might at most help preserve the current terms of trade and distribution of competitiveness among Member States. There is not much in the Green Deal as initially formulated to suggest that the current distribution of competitiveness itself should be modified to favor poorer regions and workers. Even the idea of relaxing state aid rules mentioned by the Commission is conditioned on the presence of projects involving more than one Member State, ${ }^{192}$ and nothing is said to suggest that such projects must be structured to redistribute competitiveness and income towards lower-income states.

\footnotetext{
${ }^{184}$ Effort-Sharing: Member States' Emissions Targets, EuR. Comm'N, https://ec.europa.eu/clima/policies/effort_en (last visited July 17, 2020). These decisions concern the sectors not covered by the ETS trading system.

${ }^{185}$ See LANGLET \& MAHMOUdi, supra note 44, at 261-62.

${ }^{186}$ See European Green Deal, supra note 1, at 9.

${ }^{187} I d$.

${ }^{188} I d$. at 16

${ }^{189} \mathrm{Id}$.

${ }^{190} I d$.

${ }^{191}$ See Greenhouse Gas Emission Statistics - Emission Inventories, EurostAT, (June 18, 2020), https://ec.europa.eu/eurostat/ statistics-explained/pdfscache/1180.pdf.

${ }^{192}$ This follows from the definition of "Project of Common European Interest," which the Green Deal mentions. See supra note 187 and accompanying text; see also Communication From the Commission - Criteria for the Analysis of the
} 
The most immediate implication of my analysis, then, is that existing redistributive EU environmental law mechanisms should be amplified. Because the current EU monetary architecture is very punishing of current account deficits-certainly when compared, for example, to the international monetary system's bestowing on the United States of the exorbitant privilege to run perpetual current-account deficits ${ }^{193}$-any loss of competitiveness by lower-income Member States should be compensated. The easiest way to do this is the strategy I mentioned above-allowing state aid for lower-income countries to neutralize their increased environmental regulatory costs. And even once the ambitious European Green Deal regulatory obligations have been compensated for, we should continue to allow state aid beyond those regulatory costs, until we equalize competitiveness and national incomes to the extent required by our normative theory of international justice and desert.

Allowing for compensation of competitiveness-reducing environmental regulations is a necessary part of my proposed policy approach. But, without more, this leaves lower-income Member States to shoulder the costs of such compensation. A better policy would be to transfer resources from higher- to lower-income Member States to ensure that the redistribution of competitiveness by allowing domestic subsidies results in more of a redistribution of economic well-being. The European Green Deal's proposal to use EU budget resources to finance the greening of production processes is a useful tool for this purpose, given that richer Member States contribute more to the EU budget than poorer ones. As noted above, however, if such European subsidies come not from the normal EU budget contributions but from environmental taxes that fall at least partly on lower-income Member States, the redistributive aim of my proposal is, to that extent, thwarted. ${ }^{194}$ The precise ways in which the post-COVID recovery plan will be financed, the object of complex negotiations as this Article was being finished, will determine in large part how the costs of the Green Deal EU-level fiscal measures will be distributed.

An alternative to using new European fiscal measures is to leave the financial costs of greening production processes to Member States but to use central bank policy to reduce the cost of debt of lower-income Member States. ${ }^{195}$ This latter alternative has the downside that it would only apply to Eurozone countries. Another arguably simpler way to transfer resources is to grant more ETS allowances to lower-income Member States for them to auction. This can be done by increasing the share of allowances specifically dedicated to lower-income states that I mentioned above. ${ }^{196}$ Alternatively, we can abandon the general rule of attributing allowances on the basis of current greenhouse gas emissions, highly correlated with national income, and attribute them on a per capita basis. ${ }^{197}$ It bears notice that whichever one of these mechanisms ends up being chosen is likely to be more effective at redistributing income than the Just Transition Mechanism - which is the European Green Deal's instrument specifically dedicated to addressing distributive issues but focused on more polluting regions instead of poorer ones.

Any successful redistribution of competitiveness will cause job losses on the side of richer Member States that will face more competitive import-competing products abroad and more competitive exports coming into their borders. In order to avoid inequality worsening within

\footnotetext{
Compatibility With the Internal Market of State Aid to Promote the Execution of Important Projects of Common European Interest, $\$ 3.2 .1,2014$ O.J. (C 188) 4, 7.

${ }^{193}$ See, e.g., Greta Krippner, Capitalizing on Crisis: The Political Origins of the Rise of Finance $86-105$ (2011).

${ }^{194}$ See supra notes 65-66 and accompanying text.

${ }^{195}$ As mentioned above, these monetary aspects are largely outside the scope of this Article. See supra note 71 and accompanying text.

${ }^{196}$ See supra note 185 and accompanying text.

${ }^{197}$ See Eric A. Posner \& Cass R. Sunstein, Should Greenhouse Gas Permits Be Allocated on a Per Capita Basis?, 97 CALIF. L. Rev. 51, 65-66 (2009). Posner and Sunstein describe this strategy and argue it would not be generally egalitarian because population size is not always correlated with low income. Id. But if GDP per capita is correlated with greenhouse gas emissions per capita, it seems to me that switching from allocating allowances based on current emissions to allocating them on a per capita basis always redistributes in an egalitarian direction, contrary to what Posner and Sunstein argue.
} 
the richer Member States and gilets jaunes-type protests springing up against the environmental agenda, a plan for a just transition will be needed within richer states too. And those who hold egalitarian political philosophies should also insist that redistribution be made central to the transition policies within the richer Member States. One possible approach would be to focus green policies in the richer Member States on sectors producing non-tradable goods and services. So, for instance, we might imagine state-led job guarantee programs ${ }^{198}$ that massively invest in increasing the energy performance of buildings throughout the country. ${ }^{199} \mathrm{Or}$, the same kind of program might aim at restructuring city infrastructure and transport to eliminate as much polluting transportation as possible.

The line I am proposing we draw-between goods that cross borders and non-tradable goods and services, such as those tied to an immobile building or a transportation network-is arguably somewhat arbitrary. Just as tradable goods can cross borders, firms from poorer Member States can travel to perform the non-tradable services in the place of richer-Member-State firms, as in the Laval case where Latvian workers and firms came to Sweden to take up unionized workers' construction jobs. ${ }^{200}$ But accepting much redistribution of competitiveness as to tradable-good production and limiting such redistribution (i.e. applying uniform environmental standards without compensating subsidies) in non-tradable sectors has the merit of drawing a relatively clear line. This might offer a sensible compromise between total redistribution of market shares towards poorer countries and the protection of richer-country markets against poorer-country competition. In those non-tradable richer-country sectors, then, an ambitious policy of social protection and perhaps even worker control of firms can be put in place to move the environmental transition along an egalitarian trajectory on all fronts.

\section{E. Conclusion}

In this Article I have proposed an incorporation of labor law and workers' rights into environmental policy that entirely focuses on the differentiated impact of environmental laws on workers in different territories competing with each other on goods markets. I have focused on a subset of environmental measures - those that raise production costs in traded-good industries-disregarding many other environmental measures both present in and pre-existing the Green Deal. This has had several consequences for the scope of this Article, including that I have ignored much labor law scholarship and policy reflection on the impact of the green transition on jobs quite apart from competitiveness concerns. ${ }^{201}$ Instead, I have drawn on international environmental law, trade, and development theory in my discussion of labor and workers' rights in the Green Deal. This choice was inspired in part by years of thinking about the impact of the Eurozone debt crisis, argued to be rooted in trade competitiveness issues, on the rights of workers. ${ }^{202}$ Extending some of these themes to the environmental transition seemed like a worthwhile contribution.

\footnotetext{
${ }^{198}$ See Pavlina R. Tcherneva, The Job Guarantee: Delivering the Benefits That Basic Income Only Promises - A Response to Guy Standing, 7 BASIC INCOME STUDIEs 66, 68-69 (2013) (describing a state-led job guarantee program).

${ }^{199}$ Some inspiration can be drawn from the Directive 2010/31 of the European Parliament and of the Council on the Energy Performance of Buildings, 2010 O.J. (L 153) 13.

${ }^{200}$ Case C-341/05, Laval un Partneri Ltd v. Svenska Byggnadsarbetareförbundet, 2007 E.C.R. I-11767.

${ }^{201}$ See, e.g., Anabella Rosemberg, Building a Just Transition: The Linkages Between Climate Change and Employment, 2 INT'L J. LAB. RsCH. 125, 145-46 (2010); David J. Doorey, A Transnational Law of Just Transitions for Climate Change and Labour, in Research Handbook On Transnational Labour Law 551, 558-60 (Adelle Blackett \& Anne Trebilcock eds., 2015). I would say the International Labor Organization's work in the area of environmental justice also deals with labor issues without detailed engagement with trade. See Environment and Climate Change, INT'L LAB. ORG., https://www.ilo.org/actrav/areas/ WCMS_DOC_ATR_ARE_ENV_EN/lang-en/index.htm (last visited July 17, 2020).

${ }^{202}$ The following piece influenced me early on: Kerry Rittich, Fragmented Work and Multi-Level Labour Market Governance: Informality, Crisis Policy and an Expanded 'Law of Work', in CritiCAL Legal PersPeCtives ON GlOBAL Governance: Liber Amicorum David M. TrubeK 185 (Grainne de Burca, Claire Kilpatrick \& Joanne Scott eds., 2014).
} 
My argument has largely been that any EU environmental agenda will distribute well-being asymmetrically among workers in different regions, and that these impacts should be openly assessed. Moreover, I have argued, based on a legal institutionalist approach, that trade law always does such distributive work. Because legal institutionalism teaches us that all legal rules and institutions subsidize production, only a fraction of instances of state aid gets adjudicated at the EU level. The work of trade law in distributing well-being therefore lies just as much in the outcomes of actual state aid cases as in the domestic rules and institutions that are ignored and uncontested as firms in one region or country benefit from them. Additionally, because there will always be losers from the pursuit of egalitarian redistribution of competitiveness, I have argued we must have not only a plan for such redistribution but also one to compensate the losers from redistribution in the richer countries. Building local green industrial policies in German or Dutch cities instead of having firms from those countries storm the markets of lower-income Member States has been my tentative proposal. There might be better ideas to try as we set out to implement the general policy approach sketched here.

In presenting my argument, I have disregarded countries outside the European Union and focused on intra-EU distributive justice issues. But of course, the same distributive analysis may be conducted of countries outside Europe that have lower incomes than any EU Member State. And if Bulgaria's national per capita income of 22,405 USD, the lowest in the EU and 2.5 times lower than Germany's 55,155 USD, easily qualifies it as a candidate for intra-EU redistribution, Egypt's national per capita income of 11,079 USD surely gives that country a trump card for consideration by an egalitarian-minded European policy-maker. ${ }^{203}$

The European Green Deal does address countries outside the EU and proposes a "carbon border adjustment mechanism," i.e. a tax on imports, to avoid newly-green EU producers being outcompeted by non-green producers from outside Europe. ${ }^{204}$ The stated goal is to avoid "carbon leakage," whereby greener EU products are replaced by non-green products from abroad, leaving pollution at the same level as before. Unsurprisingly, subsidies to European producers are also discussed as alternative means to neutralize non-green competition from outside Europe. ${ }^{205}$ There already existed measures to give European producers an added edge over non-European ones before the European Green Deal, moreover. The ETS, in particular, distributed extra pollution allowances to sectors vulnerable to competition from abroad so as to reduce their environmental regulatory costs. ${ }^{206}$

I have seen no acknowledgement that such protection of EU firms will at best maintain the existing terms of trade between Europe and the rest of the world-and that this might be unjust. ${ }^{207}$ The lack of such an acknowledgement is quite evident when the Commission promises to "use its expertise in 'green' regulation to encourage partners to design similar rules that are as ambitious as the EU's rules, thus facilitating trade and enhancing environment protection and climate mitigation in these countries." ${ }^{208}$ Of course, if the other country in question is the United States, there is no plausible political or moral objection to transferring the costs of EU environmental measures onto import prices. But if the other country is one like Egypt, the situation is different-this Article's analysis of the justice of asymmetric trade competitiveness applies, although in a more

\footnotetext{
${ }^{203}$ GNI per capita, PPP (current international \$), THE WORLD BANK, https://data.worldbank.org/indicator/NY.GNP.PCAP. PP.CD (last visited July 17, 2020). These numbers are from 2018.

${ }^{204}$ European Green Deal, supra note 1 , at 5.

${ }^{205}$ See Simone Borghesi, A Note on Energy Policies for Sustainability After Covid-19, EUR. U. INST. (April 20, 2020), https:// fsr.eui.eu/a-note-on-energy-policies-for-sustainability-post-covid-19/.

${ }^{206}$ See LEE, supra note 36, at 140.

${ }^{207}$ This is not to say the EU otherwise offers no assistance to lower-income countries outside Europe to "green" their economies. For example, it pledged about 750 million Euros to such countries, a symbolically important, but ultimately small, gesture. See What is the GCCA+ Initiative?, Glob. Climate Change Alliance Plus, www.gcca.eu/about-gcca (last visited July 17, 2020).

${ }^{208}$ European Green Deal, supra note 1, at 21.
} 
complex context. Indeed, policy-makers might be forced to choose between empowering Bulgarian industries vis-à-vis German ones or Egyptian ones vis-à-vis both. It might be that sometimes it is less disruptive to empower Bulgaria and shut Egypt out. There might even be extreme cases where maintaining German industrial hegemony is preferable to any redistribution. Tradeoffs and strategic planning to maximize distributive benefits and minimize the costs of redistribution will have to be the order of the day. But, as I have argued, this was always our predicament to begin with, and the needed intensification of the environmental transition only highlights tensions and hard choices that have long been ours to make. 